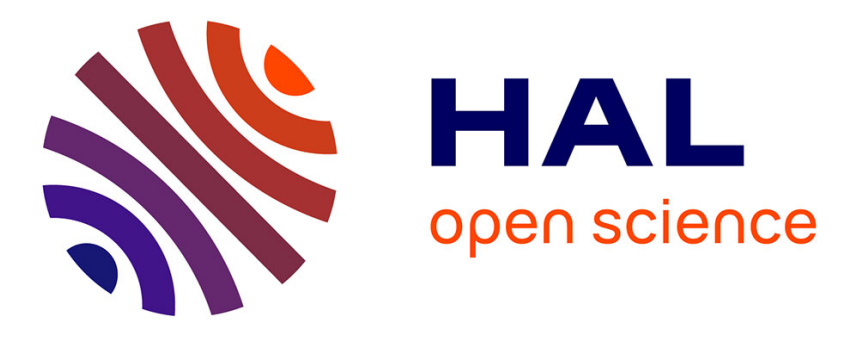

\title{
Cu-doping of calcium phosphate bioceramics: From mechanism to the control of cytotoxicity
}

Sandrine Gomes, C. Vichery, Stéphane Descamps, Hervé Martinez, Amandeep Kaur, Aurélie Jacobs, Jean-Marie Nedelec, Guillaume Renaudin

\section{- To cite this version:}

Sandrine Gomes, C. Vichery, Stéphane Descamps, Hervé Martinez, Amandeep Kaur, et al.. Cu-doping of calcium phosphate bioceramics: From mechanism to the control of cytotoxicity. Acta Biomaterialia, 2018, 65, pp.462-474. 10.1016/j.actbio.2017.10.028 . hal-01678838

\section{HAL Id: hal-01678838 \\ https://hal.science/hal-01678838}

Submitted on 1 Dec 2020

HAL is a multi-disciplinary open access archive for the deposit and dissemination of scientific research documents, whether they are published or not. The documents may come from teaching and research institutions in France or abroad, or from public or private research centers.
L'archive ouverte pluridisciplinaire HAL, est destinée au dépôt et à la diffusion de documents scientifiques de niveau recherche, publiés ou non, émanant des établissements d'enseignement et de recherche français ou étrangers, des laboratoires publics ou privés. 


\section{Cu-doping of calcium phosphate bioceramics: from mechanism to the control of cytotoxicity}

Sandrine Gomes ${ }^{1}$, Charlotte Vichery ${ }^{1}$, Stéphane Descamps ${ }^{1}$, Hervé Martinez ${ }^{2}$, Amandeep Kaur $^{1 \#}$, Aurélie Jacobs ${ }^{1}$, Jean-Marie Nedelec ${ }^{1}$, Guillaume Renaudin ${ }^{1 *}$

${ }^{1}$ Université Clermont Auvergne, CNRS, SIGMA Clermont, ICCF, F-63000 ClermontFerrand, France.

${ }^{2}$ Université de Pau et des Pays de l'Adour, IPREM CNRS UMR 5254, Helioparc Pau Pyrénées, 2 Avenue de Président Angot, F-64053 Pau Cedex 9, France.

*corresponding author: guillaume.renaudin@ sigma-clermont.fr Tel.: 00334734073 36, Fax.: 0033473407095

\# Present address: VIT University, Vellore, Tamil Nadu 632014, India. 


\section{Abstract:}

In this study, the $\mathrm{Cu}$-doping mechanism of Biphasic Calcium Phosphate (BCP) was thoroughly investigated, as was its ionic release behavior, in order to elucidate cytotoxicity features of these bioceramics. BCP are composed of hydroxyapatite $\left(\mathrm{Ca}_{10}\left(\mathrm{PO}_{4}\right)_{6}(\mathrm{OH})_{2}\right)$ and $\beta$-TCP $\left(\mathrm{Ca}_{3}\left(\mathrm{PO}_{4}\right)_{2}\right)$. The two phases present two different doping mechanisms. Incorporation into the $\beta$-TCP structure is achieved at around $700^{\circ} \mathrm{C}$ thanks to a substitution mechanism leading to the $\mathrm{Cu}$ doped $\mathrm{Ca}_{3-x} \mathrm{Cu}_{x}\left(\mathrm{PO}_{4}\right)_{2}$ compound. Incorporation into the HAp structure is achieved thanks to an interstitial mechanism that is limited to a $\mathrm{Cu}$-poor $\mathrm{HAp}$ phase for temperatures below $1100^{\circ} \mathrm{C}$ $\left(\mathrm{Ca}_{10} \mathrm{Cu}_{x}\left(\mathrm{PO}_{4}\right)_{6}(\mathrm{OH})_{2-2 x} \mathrm{O}_{2 x}\right.$ with $\left.x<0.1\right)$. Above $1100^{\circ} \mathrm{C}$, the same interstitial mechanism leads to the formation of a Cu-rich HAp mixed-valence phase $\left(\mathrm{Ca}_{10} \mathrm{Cu}^{2+}{ }_{x} \mathrm{Cu}^{+}{ }_{y}\left(\mathrm{PO}_{4}\right)_{6}(\mathrm{OH})_{2-2 x-y} \mathrm{O}_{2 x+y}\right.$ with $x+y \sim 0.5)$. The formation of both high-temperature $\mathrm{Cu}$-doped $\alpha$-TCP and $\mathrm{Cu}_{3}\left(\mathrm{PO}_{4}\right)_{2}$ phases above $1100^{\circ} \mathrm{C}$ induces a transformation into the $\mathrm{Cu}$-rich $\mathrm{HAp}$ phase on cooling. The linear $\mathrm{O}-\mathrm{Cu}-\mathrm{O}$ oxocuprate entity was confirmed by EXAFS spectroscopy, and the mixed $\mathrm{Cu}^{+} / \mathrm{Cu}^{2+}$ valence was evidenced by XPS analyses. Ionic releases $\left(\mathrm{Cu}^{+} / \mathrm{Cu}^{2+}, \mathrm{Ca}^{2+}, \mathrm{PO}_{4}{ }^{2-}\right.$ and $\mathrm{OH}^{-}$) in water and in simulated body media were investigated on as-synthesized ceramics to establish a pretreatment before biological applications. Finally the cytotoxicity of pretreated disks was evaluated, and results confirm that $\mathrm{Cu}$-doped $\mathrm{BCP}$ samples are promising bioceramics for bone substitutes and/or prosthesis coatings.

Keywords: Copper-doping, Hydroxyapatite, X-ray Diffraction, X-ray Absorption Spectroscopy, X-ray Photoelectron Spectroscopy, Cytotoxicity. 


\section{1- Introduction}

The utilization of synthetic materials for bone reconstructive surgery is generally necessary, because autograft and allograft practice is limited by the quantity of available material and entails a second surgical procedure in the first case [1]. Among the numerous synthetic materials investigated for bone replacement and/or prosthesis coating, hydroxyapatite (HAp, $\left.\mathrm{Ca}_{10}\left(\mathrm{PO}_{4}\right)_{6}(\mathrm{OH})_{2}\right)$ is the most often-used material due to its chemical and structural similarities with the bone mineral constituent [2-5]. Biological apatite refers to the main constituent of bone and hard tissue in mammals: a poorly crystallized non-stoichiometric carbonate-containing HAp that composes about 65 weight percent (wt \%) of bone and about 90 wt $\%$ of dental enamel [6]. Apatite is a complex and diverse class of materials, with a flexible structure that accepts many substitutions; either cationic or anionic [7]. Because biological apatites are formed in biological conditions, they usually contain a large variety of trace elements (F, Si, Sr, Mg, etc.) that can have specific biological properties. The incorporation of selected doping elements can be used advantageously to tune the bioactivity of the implant: antibacterial, anti-inflammatory, anti-osteoporotic or angiogenic properties, for instance. Biphasic calcium phosphates (BCP) are composed of a mixture of HAp with tricalcium phosphate $\left(\beta\right.$-TCP, $\left.\mathrm{Ca}_{3}\left(\mathrm{PO}_{4}\right)_{2}\right)$. BCP are interesting bioceramics because of the difference in the solubility of the two compounds, which allows the kinetic release of the doping elements to be regulated. A fast release occurs with $\beta$ TCP immediately after a surgical operation, whereas a continuous effect is then ensured with HAp. Our previous studies have described in detail the temperature-dependent mechanism of $\mathrm{Zn}^{2+}$ insertion in BCP bioceramics [8-10]. Contrary to previous reports in the literature, $\mathrm{Zn}^{2+}$ incorporates the HAp structure into an interstitial crystallographic site (Wyckoff site $2 b$ ) leading to an insertion solid solution of general composition $\mathrm{Ca}_{10} \mathrm{Zn}_{x}\left(\mathrm{PO}_{4}\right)_{6}(\mathrm{OH})_{2-2 x} \mathrm{O}_{2 x}$ with a constant $\mathrm{Ca} / \mathrm{P}$ ratio of 1.67 . The insertion of $\mathrm{Zn}^{2+}$ is performed for temperatures above $900^{\circ} \mathrm{C}$. For lower temperatures, Zn-doping is mainly efficient for the $\beta$-TCP phase, evincing a calcium substitution mechanism $\mathrm{Ca}_{3-x} \mathrm{Zn}_{x}\left(\mathrm{PO}_{4}\right)_{2}$. Recent works on Fe-doping have confirmed this 
temperature-dependent process leading to a HAp interstitial mechanism for temperatures above $900^{\circ} \mathrm{C}$ [11]. A complete study of 3d-metal cation (from $\mathrm{Mn}$ to $\mathrm{Zn}$ ) incorporation in $\mathrm{BCP}$ has confirmed a global equivalent doping mechanism with interesting characteristics [12]. In order to perfectly interpret the biological behavior of doped bioceramics, it is of great importance to correctly characterize the structural location of the doping elements. Metal ions such as $\mathrm{Zn}^{2+}$, $\mathrm{Cu}^{2+}$ and $\mathrm{Ag}^{+}$are known not to be cytotoxic at low concentrations, and to exhibit antimicrobial/bactericidal activity at the site of the implantation materials [13-19]. However, the biological responses of the dopant strongly depend on its release amount and kinetic [20]. Jin et al. published last year a review of the development of bio-functional $\mathrm{Cu}$ containing biomaterials (including copper-doped HAp), illustrating the renewed interest in copper bioactivity [21].

The present study aims to fully investigate the $\mathrm{Cu}$-doped $\mathrm{BCP}$ system. Besides its antimicrobial activity, copper is an essential trace element, necessary for mammalian life [22] and it plays a role in the cross-linking of collagen and bone elastin [23-25]. $\mathrm{Cu}^{2+}$ ions have been reported to enhance angiogenesis potential, osteostimulation and antibacterial properties [26-28], to stimulate the proliferation of endothelial cells [29], to promote wound healing in rats [30,31], and to enhance cell activity and the proliferation of osteoblastic cells [32]. A recent study on copper containing glass-ceramic has shown the interesting potential of $\mathrm{Cu}^{2+}$ doping for bioactivity and biocompatibility, with the necessity to control the $\mathrm{CuO}$ content, i.e. to manage $\mathrm{Cu}^{2+}$ release, in order to tune activity and viability [20,33]. Several hydroxyapatite copper doping mechanisms have so far been described in the literature. Whereas some authors have presented a substitution mechanism [34-36], others have described an insertion mechanism with the formation of linear $\mathrm{O}-\mathrm{Cu}-\mathrm{O}$ entities $[12,37-39]$ and the possible presence of mixed $\mathrm{Cu}^{+} / \mathrm{Cu}^{2+}$ valence. It is necessary to investigate in detail and correctly describe the mechanism of incorporating copper into $\mathrm{BCP}$ in order to $1 /$ adequately prepared the doped ceramic, and $2 /$ understand and tune the biological behavior of $\mathrm{Cu}$-doped $\mathrm{BCP}$ bioceramics. Our prepared $\mathrm{Cu}$ - 
doped disks were evaluated with respect to ionic release in simulated biological media (DMEM), and in terms of cytotoxicity using human mesenchymal cells in order to be close to clinical conditions.

\section{2- Materials and methods}

\subsection{Sol-gel elaboration of $C u$-doped BCP samples}

The sol-gel route previously proposed by the authors was used to synthesize both undoped and $\mathrm{Cu}$-doped series of BCP samples [8]. Briefly, to produce $2 \mathrm{~g}$ of undoped BCP powder, $4.7 \mathrm{~g}$ of $\mathrm{Ca}\left(\mathrm{NO}_{3}\right)_{2} .4 \mathrm{H}_{2} \mathrm{O}$ (Aldrich) and $0.84 \mathrm{~g}$ of $\mathrm{P}_{2} \mathrm{O}_{5}$ (Avocado Research chemicals) were dissolved in ethanol under stirring and refluxed at $85^{\circ} \mathrm{C}$ for 24 hours. The solution was then maintained at $55^{\circ} \mathrm{C}$ for 24 hours to obtain a white consistent gel, and further heated at $80^{\circ} \mathrm{C}$ for 10 hours to obtain a white powder. Finally, the powder was heat-treated for 15 hours. This heat treatment was performed at $500^{\circ} \mathrm{C}, 600^{\circ} \mathrm{C}, 700^{\circ} \mathrm{C}, 800^{\circ} \mathrm{C}, 900^{\circ} \mathrm{C}, 1000^{\circ} \mathrm{C}, 1100^{\circ} \mathrm{C}, 1150^{\circ} \mathrm{C}$ and $1200^{\circ} \mathrm{C}$. Required amounts of $\mathrm{Cu}\left(\mathrm{NO}_{3}\right)_{2} \cdot 3 \mathrm{H}_{2} \mathrm{O}$ (Sigma-Aldrich) were added to the solution simultaneously with $\mathrm{Ca}\left(\mathrm{NO}_{3}\right)_{2} \cdot 4 \mathrm{H}_{2} \mathrm{O}$ (Sigma-Aldrich) in order to synthesize the $\mathrm{Cu}$-doped series. To obtain a series of nine samples with the same copper-containing amount, a single batch was prepared for each series and used for all the subsequent heat treatments. Nominal compositions were calculated, assuming the insertion of $\mathrm{Cu}^{2+}$ cations in the interstitial crystallographic site (i.e. $\mathrm{Ca} / \mathrm{P}=1.67$ ), similarly to previous results for the $\mathrm{Zn}^{2+}$ insertion mechanism [8-10]. In the following, the samples are labelled ' $x \mathrm{Cu}-T$ ' with $x=00,10,15,25$, 50 and 75 for samples with respectively the targeted nominal $\mathrm{Ca}_{10}\left(\mathrm{PO}_{4}\right)_{6}(\mathrm{OH})_{2}$ (i.e. undoped), $\mathrm{Ca}_{10} \mathrm{Cu}_{0.10}\left(\mathrm{PO}_{4}\right)_{6}(\mathrm{OH})_{1.80} \mathrm{O}_{0.20}, \quad \mathrm{Ca}_{10} \mathrm{Cu}_{0.15}\left(\mathrm{PO}_{4}\right)_{6}(\mathrm{OH})_{1.70} \mathrm{O}_{0.30}, \quad \mathrm{Ca}_{10} \mathrm{Cu}_{0.25}\left(\mathrm{PO}_{4}\right)_{6}(\mathrm{OH})_{1.50} \mathrm{O}_{0.50}$, $\mathrm{Ca}_{10} \mathrm{Cu}_{0.50}\left(\mathrm{PO}_{4}\right)_{6}(\mathrm{OH})_{1.00} \mathrm{O}_{1.00}$ and $\mathrm{Ca}_{10} \mathrm{Cu}_{0.75}\left(\mathrm{PO}_{4}\right)_{6}(\mathrm{OH})_{0.50} \mathrm{O}_{1.50}$ compositions. In this label, $T$ indicates the sintering temperature. More than 50 samples were prepared and characterized. A low-doped $10 \mathrm{Cu}-T$ series was used for dopant release and cell viability studies. Elemental analyses of the samples by ICP-AES confirmed the targeted nominal compositions. Sample 
color is sintering-temperature dependent. As-prepared powders obtained after the sol-gel process were blue. Heat treatments at $500^{\circ} \mathrm{C}$ produced grey samples: from light grey to dark grey as the amount of copper increased. Samples still had a grey color up to $1000^{\circ} \mathrm{C}$, and became purple from $1100^{\circ} \mathrm{C}$. Finally, heat treatments at $1200^{\circ} \mathrm{C}$ resulted in dark purple powders.

\subsection{X-Ray Powder diffraction (XRPD) and Rietveld analyses}

XRPD patterns were recorded on a Philips X'Pert Pro PANalytical diffractometer (Almelo, Netherlands), with $\theta-\theta$ geometry, reflection mode, equipped with a solid detector X-Celerator and using $\mathrm{Cu} \mathrm{K} \alpha$ radiation $(\lambda=1.54184 \AA$ ). XRPD patterns were recorded at room temperature in the interval $3^{\circ}<2 \theta<120^{\circ}$, with a step size of $\Delta 2 \theta=0.0167^{\circ}$ and a counting time of $200 \mathrm{~s}$ for each data value. The 45 synthesized samples from series $00 \mathrm{Cu}-T, 15 \mathrm{Cu}-T, 25 \mathrm{Cu}-T$ and $75 \mathrm{Cu}-T$ series were systematically analyzed by XRPD in reflection mode.

Two supplementary measurements were collected for samples $75 \mathrm{Cu}-1100$ and $75 \mathrm{Cu}-1200$ using Debye-Scherrer geometry (transmission mode) to improve diffraction peak resolution (2 theta resolution). Transmission measurements were recorded using a Philips X'Pert Pro

diffractometer equipped with a Ge hybrid monochromator $\left(\mathrm{Cu} \mathrm{K} \alpha_{1}=1.54056 \AA\right)$. A total counting time of 40 hours was used in the range $3^{\circ}<2 \theta<120^{\circ}$, with a step size of $\Delta 2 \theta=$ $0.0167^{\circ}$, using a $0.3 \mathrm{~mm}$ diameter filled glass capillary.

In-situ temperature-dependent XRPD patterns were recorded for the $75 \mathrm{Cu}-T$ series. XRPD patterns were collected on a Philips X'Pert Pro diffractometer equipped with a high-temperature HTK chamber (Anton Paar, Graz, Austria) with the following measurement conditions: two theta range $8^{\circ}<2 \theta<100^{\circ}$, step size $\Delta 2 \theta=0.0167^{\circ}$, time per step $=165 \mathrm{~s}$. A series of diffraction patterns was recorded, from $500^{\circ} \mathrm{C}$ up to $1200^{\circ} \mathrm{C}$ (using the starting $75 \mathrm{Cu}-500$ sample). Data were collected at $500^{\circ} \mathrm{C}, 600^{\circ} \mathrm{C}, 700^{\circ} \mathrm{C}, 800^{\circ} \mathrm{C}, 900^{\circ} \mathrm{C}, 1000^{\circ} \mathrm{C}, 1100^{\circ} \mathrm{C}, 1150^{\circ} \mathrm{C}$ and $1200^{\circ} \mathrm{C}$. Then data measurements were performed during the cooling from $1200^{\circ} \mathrm{C}$ to room temperature: $1150^{\circ} \mathrm{C}, 1100^{\circ} \mathrm{C}$, steps of $100^{\circ} \mathrm{C}$ down to $100^{\circ} \mathrm{C}$ and finally $25^{\circ} \mathrm{C}$. 
Rietveld refinements were systematically performed for each measurement using the program FullProf.2k [40]. The Rietveld strategy was detailed in a previous related work [8].

\section{$2.3 \underline{X \text {-ray Absorption Spectroscopy }(X A S)}$}

Cu K-edge Extended X-ray Absorption Fine Structure (EXAFS) spectra, simultaneously with the X-ray Absorption Near Edge Structure (XANES) part of the spectra, were collected on the $\mathrm{Cu}$-doped samples from the $15 \mathrm{Cu}-T$ series and one reference compound $(\mathrm{CuO})$ at the SuperXAS beam line at the SLS synchrotron (Villigen, Switzerland) in order to determine the electronic state, as well as to describe accurately the coordination spheres of the $\mathrm{Cu}$ atoms. Samples from the $15 \mathrm{Cu}-T$ series were chosen because other series present higher amounts of $\mathrm{CuO}$ impurities. The SLS synchrotron was running at $4.5-35 \mathrm{keV}$ with an average current of $400 \mathrm{~mA}$. The Xray beam was obtained with a two-crystal $\mathrm{Si}(111)$ monochromator, which features an energy resolution of $\Delta \mathrm{E} / \mathrm{E}=2.0 \times 10^{-4}$, necessary to resolve the XANES structure. The experiments were calibrated using a $\mathrm{Cu}$ metallic reference foil (K-edge $8981 \mathrm{eV})$. Experiments were performed at room temperature and atmospheric pressure. Spectra were collected in an energy range of between 8500 and $9500 \mathrm{eV}$, with energy steps varying from $0.5 \mathrm{eV}$ (XANES part) to $2.0 \mathrm{eV}$ (end of the EXAFS part) and a 1s dwell time per point. XAS spectra were obtained in fluorescence mode using Ge-solid-state detectors (13-element detector). The size of the beam was determined by a set of slits $(200 \mu \mathrm{m} \times 500 \mu \mathrm{m})$. Data was processed using the Athena and Artemis programs from the IFFEFIT software package [41] by merging 4 successivelyrecorded absorption spectra. Single scattering theory was used here. Following LengelerEisenberg normalization, EXAFS oscillations were Fourier Transformed (FT) using a Hanning window between 3.0 and $9.0 \AA^{-1}$. The $\chi(k)$ function was Fourier transformed using $k^{3}$ weighting, and all shell-by-shell fitting was done in $R$-space. Theoretical backscattering paths were calculated using successively ATOMS [42] and FEFF6 [43]. 


\section{$2.4 \underline{X \text {-ray Photoelectron Spectroscopy }(X P S)}$}

XPS measurements were carried out to determine the mean oxidation state of $\mathrm{Cu}$ with a Thermo Scientific K-Alpha X-ray photoelectron spectrometer using focused monochromatized Al Ka radiation $(\mathrm{h} v=1486.6 \mathrm{eV})$. The XPS spectrometer was directly connected through a glove box under argon atmosphere in order to avoid exposing the samples to moisture or air. For the $\mathrm{Ag}$ 3d5/2 line the full width at half-maximum (FWHM) was $0.50 \mathrm{eV}$ under the recording conditions. The X-ray spot size was $400 \mu \mathrm{m}$. Peaks were recorded with a constant pass energy of $20 \mathrm{eV}$. The pressure in the analysis chamber was less than $1 \times 10^{-8} \mathrm{~Pa}$. Short acquisition time spectra were recorded at the beginning and at the end of each experiment to check that the samples did not suffer from degradation during the measurements. Peak assignments were made with respect to reference compounds analyzed in the same conditions. The binding energy scale was calibrated from the hydrocarbon contamination using the $\mathrm{C} 1 \mathrm{~s}$ peak at $285.0 \mathrm{eV}$. Core peaks were analyzed using a nonlinear Shirley-type background [44]. The peak positions and areas were optimized by a weighted least-square fitting method using 70\% Gaussian and 30\% Lorentzian line shapes. Quantification was performed on the basis of Scofield's relative sensitivity factors [45]. For each sample, several XPS analyses were performed at different positions to ensure that the results were statistically reliable.

\section{$2.5 \underline{\text { MP-AES measurements }}$}

Ionic releases in both water and a culture medium used to simulate body fluid (DMEM; Dulbecco Modified Eagle Medium) were measured by Microwave Plasma - Atomic Emission Spectroscopy (4200 MP-AES from Agilent) in order to evaluate the behavior of the Cu-doped bioceramic in solution, and to determine the pretreatment of $\mathrm{Cu}$-doped $\mathrm{BCP}$ disks intended for biological applications. A series of calibration samples was prepared using a $1000 \mu \mathrm{g} / \mathrm{mL} \mathrm{Cu}$ ion normadose (diluted in $5 \% \mathrm{HNO}_{3}$ solutions, distributed by Agilent Technologies), diluted in 
a solvent similar to those of the solutions measured, which is to say $1 / 1$ ratio for DMEM/ $\mathrm{HNO}_{3}$ $2 \%$ and ultra-pure water/ $/ \mathrm{HNO}_{3} 2 \%$ solutions.

\subsection{Cytotoxicity evaluation}

Following the BCP structural characterization, the $10 \mathrm{Cu}-T\left(T=600,900\right.$ and $\left.1200^{\circ} \mathrm{C}\right)$ samples were prepared for cytotoxicity assessment and undoped copper-free samples were used as reference. The $10 \mathrm{Cu}-T$ series was chosen because of the absence of copper oxide impurities (see Table 1). Cell viability was assessed through a cell count after a period of cell culture on the studied material (using flat pressed disks). All conditions were tested in triplicate.

2.6.1 Bone Marrow Cell (BMC) preparation: human normal bone marrow cell source, isolation and in-vitro expansion of BM mesenchymal cells before use.

Human BMC were obtained from metaphysal cancellous bone collected during hip arthroplasty. Pieces of femoral metaphysis cancellous bone were gathered during surgical procedures in patients who had signed an authorization for the use of their bone for research purposes. All donors had normal hematopoietic function. The samples were collected in a sterile culture medium ( $\alpha \mathrm{MEM}$ ) and transported immediately to the culture lab. After washing once in phosphate-buffered saline (PBS) 4\% fetal calf serum (FCS), the BMC were re-suspended in a standard marrow cell culture medium consisting of $\alpha \mathrm{MEM} 10 \%$ FCS, 100 U penicillin, $100 \mu \mathrm{g} / \mathrm{mL}$ streptomycin, $2 \mathrm{mM} \mathrm{L-Glutamin}$ and plated at $1.5 \times 10^{5}$ cells $/ \mathrm{cm}^{2}$ in $25 \mathrm{~cm}^{2}$ tissue culture flasks at $37^{\circ} \mathrm{C}$ with $5 \%$ of humidified $\mathrm{CO}_{2}$ for two days. The nonadherent BMC were harvested in two gentle rinses and removed. Adherent cells were fed by a weekly change of medium. Mesenchymal cells were expanded through one of three passages (re-plated between $5 \times 10^{2}$ and $1 \times 10^{3}$ cells $/ \mathrm{cm}^{2}$ ) before being collected by trypsinization.

2.6.2 Assessment of mesenchymal cell proliferation on samples disks. 
Sterilization of each disk was completed with a sequence of ethanol (95\%) for 30 minutes followed by PBS for 30 mins; this was performed twice. The disks were placed in 24-well cell culture trays, with $8 \times 10^{3}$ cells/well seeded in each well. One disk per well was plated in triplicate in 24-well plates to produce a representative series. Each disk was sowed with the same number of expanded mesenchymal cells $\left(8 \times 10^{4}\right.$ cells $)$ in a standard medium with $700 \mu \mathrm{L}$ of medium in each, which was changed twice weekly. All disks were colonized by cells coming from the same patient during the same expansion process.

To evaluate cell viability, the wells were sacrificed to collect cells after one week of culture. Cells were harvested after detachment by trypsin/EDTA $0.25 \%$ and counted in Malassez. For each arm, we evaluated in parallel the viability of cell proliferation on equivalent uncoated plastic wells in the absence of a disk as a control, in order to estimate the effect of ceramic disks only. One extra disk was seeded in the same way and sacrificed at day 6 to study cell morphology using SEM.

\subsubsection{Statistical analysis.}

Results were expressed as means \pm standard error of mean, considering triplicate samples. Limiting Dilution Analysis (LDA) was performed according to the Poisson statistical model using L-Calc ${ }^{\mathrm{TM}}$ software (StemCell Technologies, Vancouver, Canada). Statistical analysis used the bilateral paired Student's test with a significant $\mathrm{p}$ value $<0.05$.

\section{3- Results: Materials characterization}

\subsection{Temperature-dependent phase composition of the samples}

To correctly interpret the behavior of our samples, their mineral compositions were extracted from Rietveld analyses (selected XRPD patterns are shown in Figure SEI1). Mineral compositions of the undoped BCP series and of the four $\mathrm{Cu}$-doped $\mathrm{BCP}$ series $(x=15,25,50$ and 75) of samples are indicated in Table 1. Results are extracted from XRPD measurements performed with the $\theta-\theta$ geometry except when indicated by an asterisk (transmission mode on 
capillary) in Table 1 and Table SEI1. Figure 1 represents the thermal composition variation for the two main phases: HAp and $\beta$-TCP. Other minor phases were observed. $\alpha$-CDP (diCalcium DiPhosphate with composition $\mathrm{Ca}_{2} \mathrm{P}_{2} \mathrm{O}_{7}$ ) was observed up to $700^{\circ} \mathrm{C}$, with a maximum amount - around 6-9 wt $\%$ - at $600^{\circ} \mathrm{C}$. Calcite $\mathrm{CaCO}_{3}$ was present in samples which were heat treated at $500^{\circ} \mathrm{C}$, and decarbonation mainly occurred at $600^{\circ} \mathrm{C}$. $\mathrm{CuO}$ was generally observed in samples from the $\mathrm{Cu}$-doped series - except for $15 \mathrm{Cu}-1150$ and $15 \mathrm{Cu}-1200$ (which are composed of HAp and $\beta$-TCP only) - indicating that part of the incorporated copper amount is not inserted in the two main phases. $\beta$-TCP was stabilized for intermediate temperatures and the presence of copper increased the $\beta$-TCP amount at $700^{\circ} \mathrm{C}$. Samples became almost exclusively composed of HAp phases for the higher temperatures, except for the $15 \mathrm{Cu}-T$ series with about $10 \mathrm{wt} \%$ of $\beta$-TCP remaining above $1000^{\circ} \mathrm{C}$.

Thermal variations in the HAp lattice parameters (Figure 2 and Table SEI1) showed only minor variations between undoped and $\mathrm{Cu}$-doped series from $500^{\circ} \mathrm{C}$ up to $1100^{\circ} \mathrm{C}$ (the maximum heat treatment usually used in our previous studies on BCP doping [8-12, 46-48]). Weak copper insertion into the interstitial $2 b$ Wyckoff site was observed up to $1100^{\circ} \mathrm{C}$ from Rietveld refinements on samples belonging to the four $\mathrm{Cu}$-doped series: between 1 and $5 \%$ occupancies leading to a maximum inserted copper composition $\mathrm{Ca}_{10} \mathrm{Cu}_{0.1}\left(\mathrm{PO}_{4}\right)_{6}(\mathrm{OH})_{1.8} \mathrm{O}_{0.2}$ for the $50 \mathrm{Cu}-$ 1100 sample (Table SEI1). The a lattice parameter of $\mathrm{Cu}$-doped samples heat treated at temperatures between $500^{\circ} \mathrm{C}$ and $700^{\circ} \mathrm{C}$ shows a decrease compared to the undoped series (Figure 2). Attempts to substitute calcium atoms during the Rietveld procedure (considering both the $\mathrm{Ca} 1$ and $\mathrm{Ca} 2$ crystallographic sites in the HAp structure [49]) failed, whatever the amount of copper and the sintering temperature. Higher-temperature treatments were performed $\left(1150^{\circ} \mathrm{C}\right.$ and $\left.1200^{\circ} \mathrm{C}\right)$ in order to pursue the temperature-dependent study on copper insertion. For temperatures above $1100^{\circ} \mathrm{C}$, lattice parameters sharply increased. These variations in the HAp unit cell were accompanied by a large increase in copper occupancy at the interstitial $2 b$ Wyckoff site (Figure 2 and Table SEI1). More surprisingly, samples heat treated at $1150^{\circ} \mathrm{C}$ and 
$1200^{\circ} \mathrm{C}$ from the $50 \mathrm{Cu}-T$ and $75 \mathrm{Cu}-T$ series showed systematic shoulders for almost all diffraction peaks related to the HAp structure. Such behavior can be explained by the presence of two HAp phases with slightly different lattice parameters. Rietveld refinements were then performed on XRPD patterns recorded in transmission mode on capillaries filled with the two $75 \mathrm{Cu}-1100$ and $75 \mathrm{Cu}-1200$ samples in order to improve the diffraction peak resolution (Figure 3). The presence of two HAp phases was clearly evidenced. Results indicated that one phase (HAp1 in Figure 3) corresponding to the HAp phase observed in samples heat treated below $1100^{\circ} \mathrm{C}$ relates to the previously indicated composition $\mathrm{Ca}_{10} \mathrm{Cu}_{0.1}\left(\mathrm{PO}_{4}\right)_{6}(\mathrm{OH})_{1.8} \mathrm{O}_{0.2}$; called $\mathrm{Cu}-$ poor HAp phase hereafter. The second, and new, HAp phase (HAp2 in Figure 3) presents larger lattice parameters and a larger quantity of copper cations at the interstitial site, leading to the refined $\mathrm{Ca}_{10} \mathrm{Cu}_{0.6}\left(\mathrm{PO}_{4}\right)_{6}(\mathrm{OH})_{0.8} \mathrm{O}_{1.2}$ composition, called $\mathrm{Cu}$-rich HAp phase hereafter. Figure 2 and Table SEI1 take into consideration the characteristics of these two HAp phases for the $50 \mathrm{Cu}-T$ and $75 \mathrm{Cu}-T$ series. Structural parameters of both $\mathrm{Cu}$-poor and $\mathrm{Cu}$-rich $\mathrm{HAp}$ phases from sample $75 \mathrm{Cu}-1200$ are gathered in Table 2.

The main structural parameters of the $\beta$-TCP phase in samples from each series - containing the largest amount of $\beta$-TCP phase $\left(800^{\circ} \mathrm{C}\right.$ for the undoped series and $700^{\circ} \mathrm{C}$ for the $\mathrm{Cu}$-doped series; see Table 1) - can be seen in Table SEI2. The substitution mechanism was evidenced by the decrease in the lattice parameters of its rhombohedral structure [51]. Refinement of the atomic occupancy factors showed that the substitution mechanism occurs in the low-density column [48] at both the $\mathrm{Ca} 4$ and $\mathrm{Ca} 5$ crystallographic sites - in agreement with previous observations on the transition metal insertion mechanism [8-12]. Maximum refined substitution led to the $\mathrm{Ca}_{2.72(3)} \mathrm{Cu}_{0.28(3)}\left(\mathrm{PO}_{4}\right)_{2}$ composition for $75 \mathrm{Cu}-700$ (Table SEI2). The literature already indicates the existence of $\mathrm{Ca}_{19} \mathrm{Cu}_{2}\left(\mathrm{PO}_{4}\right)_{14}$ - polymorphic to $\beta$-TCP with the same rhombohedral $R 3 c$ structure - very close to our refined composition [51]. Higher amounts of copper substitution lead to structure modifications: monoclinic $P 2_{1} / c \mathrm{Ca}_{1.5} \mathrm{Cu}_{1.5}\left(\mathrm{PO}_{4}\right)_{2}$ [52] and triclinic $P \overline{1}$ calcium-free $\mathrm{Cu}_{3}\left(\mathrm{PO}_{4}\right)_{2}[53]$. 


\subsection{Formation of the second, copper-rich, HAp phase}

In order to understand the formation mechanism of the two HAp phases for high sintering temperatures - the $\mathrm{Cu}$-poor and the $\mathrm{Cu}$-rich HAp phases - in-situ high-temperature XRPD measurements were performed on the $75 \mathrm{Cu}-T$ series. Rietveld refinements enabled the temperature-dependent quantitative phase analysis and the corresponding assemblage variation to be identified (Figure 4). The $75 \mathrm{Cu}-500$ sample was introduced into the high-temperature HTK chamber, and XRPD patterns were recorded during heating from $500^{\circ} \mathrm{C}$ up to $1200^{\circ} \mathrm{C}$ and then during cooling down to room temperature. From $500^{\circ} \mathrm{C}$ to $1000^{\circ} \mathrm{C}$, phase mixtures were coherent with those previously observed from measurements performed at room temperature on cooled samples: namely the stabilization of $\beta$-TCP observed around $700^{\circ} \mathrm{C}$. Nevertheless, above $700^{\circ} \mathrm{C}$ the amount of $\beta$-TCP remained almost unchanged, and the amount of HAp increased, together with the consumption of copper oxide $\mathrm{CuO}$. This last point was not evidenced from measurements carried out at room temperature on cooled samples, where the $\mathrm{CuO}$ amount remained constant at around $5 \mathrm{wt} \%$ (Table SEI1). Between $1000^{\circ} \mathrm{C}$ and $1100^{\circ} \mathrm{C}$ the $\beta$-TCP transformed into the $\alpha$-TCP polymorph and the tri-copper phosphate, triclinic $\mathrm{Cu}_{3}\left(\mathrm{PO}_{4}\right)_{2}$, appeared [53]. Between $1100^{\circ} \mathrm{C}$ and $1200^{\circ} \mathrm{C}$ the $\beta$-TCP phase completely disappeared and the HAp phase was considerably destabilized (about $20 \mathrm{wt} \%$ only at $1200^{\circ} \mathrm{C}$ ) to the benefit of $\alpha$-TCP and $\mathrm{Cu}_{3}\left(\mathrm{PO}_{4}\right)_{2}$. Minor changes were observed during cooling from $1200^{\circ} \mathrm{C}$ and $1100^{\circ} \mathrm{C}$. At $1000^{\circ} \mathrm{C}$, both $\alpha$ - TCP and $\mathrm{Cu}_{3}\left(\mathrm{PO}_{4}\right)_{2}$ phases disappeared, concomitantly with a large increase in the HAp phase and the formation of about 10 wt $\%$ of the $\beta$-TCP polymorph. Because of the relatively low 2-theta resolution of the XRPD patterns recorded using the HTK chamber, Rietveld refinements did not enable us to discriminate clearly the presence of two HAp phases. Cooling from $1000^{\circ} \mathrm{C}$ to room temperature did not show a significant evolution. Nevertheless, information provided by these HTK measurements indicated that the $\mathrm{Cu}$-rich HAp phase came from the transformation of both $\alpha$-TCP (certainly 
copper substituted) and $\mathrm{Cu}_{3}\left(\mathrm{PO}_{4}\right)_{2}$ phases between $1200^{\circ} \mathrm{C}$ and $1100^{\circ} \mathrm{C}$. This transformation, performed above $1100^{\circ} \mathrm{C}$, explained the absence of the $\mathrm{Cu}$-rich $\mathrm{HAp}$ phase for heat treatments up to $1100^{\circ} \mathrm{C}$ (Figure 2). The presence of both HAp1 and HAp2 phases in Figure 4 during cooling was extrapolated from previous transmission results.

\subsection{Copper location in the HAp structure}

During Rietveld refinements the occupancy factors of all calcium and phosphorus crystallographic sites were systematically tested, as well as the eventual copper substitutions at calcium sites (two crystallographic sites for HAp and five crystallographic sites for $\beta$-TCP) and copper insertion at the interstitial $2 b$ Wyckoff site. Results indicated, as already thoroughly described for $\mathrm{Zn}^{2+}$ doping, that the mechanism is temperature-dependent with a first step around $700^{\circ} \mathrm{C}$ corresponding to a substitution mechanism in the $\beta$-TCP phase, followed by an insertion mechanism in the HAp phase. The latter is fully accomplished for sintering temperatures higher than $1100^{\circ} \mathrm{C}$ to obtain the $\mathrm{Cu}$-rich $\mathrm{HAp}$ phase with the $\mathrm{Ca}_{10} \mathrm{Cu}_{0.6}\left(\mathrm{PO}_{4}\right)_{6}(\mathrm{OH})_{0.8} \mathrm{O}_{1.2}$ composition. In order to confirm this insertion mechanism, XAS analyses were performed on five samples from the $15 \mathrm{Cu}-T$ series $(15 \mathrm{Cu}-500,15 \mathrm{Cu} 600,15 \mathrm{Cu}-800,15 \mathrm{Cu}-1100,15 \mathrm{Cu}-1200$ samples: Figure SEI2) at the SuperXAS beam line at the SLS synchrotron (Villigen, Switzerland). Samples from the $15 \mathrm{Cu}-T$ series were chosen because of the lower amounts of $\mathrm{CuO}$ impurity for all samples of the series (less than $1 \mathrm{wt} \%$ and total absence for $15 \mathrm{Cu}-1200$; see Table1). EXAFS spectra were expected to enable us to evidence the formation of linear $\mathrm{O}-\mathrm{Cu}-\mathrm{O}$ entities with short $\mathrm{Cu}-\mathrm{O}$ interatomic distances. Previous Rietveld refinements did not allow this short $\mathrm{Cu}-\mathrm{O}$ interatomic distance to be determined because of statistical disorder around the oxygen atoms in the HAp hexagonal channel: the O4 crystallographic site corresponds either to oxygen from isolated hydroxyl groups or to oxygen from linear $\mathrm{O}-\mathrm{Cu}-\mathrm{O}$ entities. Rietveld analyses indicated only the wide $1.40-2.05 \AA$ range for the $\mathrm{Cu}-\mathrm{O}$ interatomic distance. Fouriertransformed amplitudes (not corrected for phase shift) are shown in Figure $5 \mathrm{~b}$ in $R$-space. Radial 
distributions for the different samples did not show great variations, and were relatively similar to that of the $\mathrm{CuO}$ reference compound in the $1 \AA-3 \AA R$ range. It should be remembered that samples were not single-phase, and several phases contribute to the spectra: copper from $\mathrm{CuO}$ impurity, substituted copper in $\beta$-TCP and inserted copper in HAp. Nevertheless, careful analysis of the radial distribution showed that the first peak is slightly displaced toward the small $R$ values for the $15 \mathrm{Cu}-1200$ sample: $1.48 \AA$ against $1.51 \AA$ for other $15 \mathrm{Cu}-T$ samples and for the $\mathrm{CuO}$ reference compound. $15 \mathrm{Cu}-1200$ is the only sample without any $\mathrm{CuO}$ impurity. Fitting the $k^{3}$-weighted EXAFS raw data of $15 \mathrm{Cu}-1200$ (Figure SEI3) confirmed the two oxygen neighbors and indicated a refined $\mathrm{Cu}-\mathrm{O}$ interatomic distance of 1.91 (1) $\AA$. This relatively short interatomic distance (compared to $\mathrm{d}_{\mathrm{Cu}-\mathrm{O}}=1.96 \AA$ in $\mathrm{CuO}$ ) agrees with the insertion mechanism of copper cations at the $2 b$ interstitial Wyckoff site, leading to linear O$\mathrm{Cu}-\mathrm{O}$ oxocuprate. The XANES part of the spectra (Figure 5a) showed the appearance of a preedge peak at $8983 \mathrm{eV}$ from a sintering temperature of $1100^{\circ} \mathrm{C}$ : a shoulder for the $15 \mathrm{Cu}-1100$ sample and a sharp pre-edge signal for the $15 \mathrm{Cu}-1200$ sample. Analysis of the EXAFS data is a direct method that probes the electronic and structural nature of the metal site [54-56]. Empirical correlations of the energies of copper X-ray absorption edge features were used to detect the presence of $\mathrm{Cu}^{+}$. It was recognized that the pre-edge feature at $8983 \mathrm{eV}$ is present in the absorption edge spectra of $\mathrm{Cu}^{+}$complexes but not in those of $\mathrm{Cu}^{2+}$. Kau and al. have shown that samples containing $\mathrm{Cu}^{+}$exhibit a near-edge absorption feature at $8983.5(3) \mathrm{eV}$, consistent with the $1 \mathrm{~s}-4 \mathrm{p}$ transition of a $\mathrm{Cu}^{+}$center, whereas $\mathrm{Cu}^{2+}$ entities do not exhibit a peak below $8985 \mathrm{eV}$ [57]. $\mathrm{Cu}^{2+}$ cations are characterized by a broader signal [58]: the shoulder of the $\mathrm{Cu}$ $\mathrm{K} \alpha$ edge observed in Figure 5a for the $\mathrm{CuO}$ reference compound and for samples $15 \mathrm{Cu}-500$, $15 \mathrm{Cu}-600$ and $15 \mathrm{Cu}-800$.

\section{$3.4 \underline{\mathrm{Cu}^{+} / \mathrm{Cu}^{2+} \text { mixed valence in } \mathrm{HAp} \text { above } 1100^{\circ} \mathrm{C}}$}


Samples from the $75 \mathrm{Cu}-\mathrm{T}$ series were analyzed by XPS spectroscopy in order to confirm the presence of $\mathrm{Cu}^{+}$cations for heat treatments above $1100^{\circ} \mathrm{C}$. XPS spectra $\left(2 \mathrm{p}_{3 / 2}\right)$ from samples $75 \mathrm{Cu}-1000$ to $75 \mathrm{Cu}-1200$, presented in Figure 6, have been interpreted according to literature peak assignments described in Comment SEI1 from supplementary information section [5962]. The $\mathrm{Cu}^{+} / \mathrm{Cu}^{2+}$ ratio was estimated for the three samples considering the following conditions (based on the spectral analyses of the reference compounds): the binding energy for $\mathrm{Cu}^{+}$is positioned at $932.7 \mathrm{eV}$ and the associated component presents a constant full width at half maximum (FWHM) of $1.3 \mathrm{eV}$ for the three samples. Furthermore, the relative proportion of $\mathrm{Cu}^{2+}$ for the $75 \mathrm{Cu}-1000,75 \mathrm{Cu}-1100$ and $75 \mathrm{Cu}-1200$ samples could be also estimated by taking into account the ratio between the main $\mathrm{Cu} 2 \mathrm{p}_{3 / 2}$ peak and the corresponding satellite peaks located in the range $940-945 \mathrm{eV}$. The $\mathrm{Cu}^{+}$amount is weak for $75 \mathrm{Cu}-1000$ (Figure 6) with an experimental $\mathrm{Cu}^{+} / \mathrm{Cu}^{2+}$ ratio of 0.03 . This ratio increases to 0.10 for $75 \mathrm{Cu}-1100$ and to 0.24 for $75 \mathrm{Cu}-1200$. Note that for the last compound $(75 \mathrm{Cu}-1200)$, the experimental envelope of the $2 p_{3 / 2}$ component presents a shoulder at low binding energy. Furthermore, the ratio between the

$\mathrm{Cu}^{2+} 2 \mathrm{p}_{3 / 2}$ contribution and the associated satellite peaks is lower than for $75 \mathrm{Cu}-1000$ and $75 \mathrm{Cu}-$ 1100 , which is in agreement with a higher proportion of $\mathrm{Cu}^{+}$in the $75 \mathrm{Cu}-1200$ sample.

Thus XPS reveals the partial $\mathrm{Cu}^{2+}$ reduction for temperatures above $1100^{\circ} \mathrm{C}$, and indicates that $\mathrm{Cu}^{+}$is inserted in the $\mathrm{Cu}$-rich HAp phase. Only about 16 atomic $\%$ of copper is in the $\mathrm{Cu}^{+}$ oxidation state in $75 \mathrm{Cu}-1200$, indicating that the $\mathrm{Cu}$-rich $\mathrm{HAp}$ phase did not contain exclusively $\mathrm{Cu}^{+}$. The $\mathrm{Cu}$-rich $\mathrm{Ca}_{10} \mathrm{Cu}_{0.6}\left(\mathrm{PO}_{4}\right)_{6}(\mathrm{OH})_{0.8} \mathrm{O}_{1.2}$ is a mixed-valence $\mathrm{Cu}^{+} / \mathrm{Cu}^{2+}$-doped HAp. It should be borne in mind that XPS is a surface analysis (depth analysis about $5 \mathrm{~nm}$ ) and that results are not necessarily bulk representative. The main and significant XPS result here is the confirmation of the $\mathrm{Cu}^{+}$electronic state, in agreement with XANES observation and the evidence of sintering temperature-dependence.

\section{4- Results: Material behavior in a biological medium}




\subsection{Ionic release}

The impact of the release of copper ions on cytotoxicity was studied for the $10 \mathrm{Cu}-T$ series, with $T=600,900$, and $1200^{\circ} \mathrm{C}$. For comparison, measurements were also performed with the undoped series. Samples with a nominal composition of $\mathrm{Ca}_{10} \mathrm{Cu}_{0.10}\left(\mathrm{PO}_{4}\right)_{6}(\mathrm{OH})_{1.80} \mathrm{O}_{0.20}$ were selected because of the absence of copper oxide impurities previously observed in the $15 \mathrm{Cu}-T$ series, and because too high a quantity of copper ions released could indeed increase cytotoxicity. In addition, samples heat-treated at the three temperatures $\left(600^{\circ} \mathrm{C}, 900^{\circ} \mathrm{C}\right.$ and $1200^{\circ} \mathrm{C}$ ) were chosen in order to vary the disk composition, the copper location and the degree of oxidation of the copper ions. As shown, a higher annealing temperature induces a higher HAp/ $\beta$-TCP ratio, which could give rise to different copper ion release kinetics, the $\beta$-TCP phase being dissolved much faster than the HAp one.

To be close to cytotoxicity test experimental conditions, in a first experiment, each disk was immersed in $20 \mathrm{~mL}$ of a solution of simulated body fluid (DMEM - Dulbecco's Modified Eagle Medium, without D-Glucose and L-Glutamine). The closed bottles were maintained at $37^{\circ} \mathrm{C}$ in an oven, with $5 \%$ of humidified $\mathrm{CO}_{2}$, for several days. As can be seen in Figure 7, after one day the concentration of copper ions in the solution was already high, and even reached $50 \mathrm{ppm}$ after 21 days for the $900^{\circ} \mathrm{C}$ annealed sample. It is interesting to note that the $\mathrm{Cu}$-doped $\mathrm{BCP}$ sample heat-treated at $1200^{\circ} \mathrm{C}$ shows a much lower copper ion release, which is directly correlated with its composition (no $\beta$-TCP phase and copper completely inserted in the weakly soluble HAp phase). The concentrations obtained, from 0.02 to $0.28 \mathrm{ppm}$ for the undoped samples, confirm the non-contamination of these samples as well as the sensitivity of the measurements. During this experiment it was noticed that the $\mathrm{pH}$ of all the solutions significantly increased, probably due to the dissolution of the small amount of $\mathrm{CaO}$ in the samples. As such a pH increase could be harmful for the cell's viability in biological conditions, a post-synthesis treatment of the disks was performed in order to remove free $\mathrm{CaO}$ before 
carrying out cytotoxicity measurements. In addition, it could be interesting to reduce the quantity of copper ions released, as a high concentration could also damage the cells.

In a second experiment, in order to dissolve $\mathrm{CaO}$ and prevent a rise in $\mathrm{pH}$ during the cytotoxicity tests, each disk was immersed in $20 \mathrm{~mL}$ of ultra-pure water, in a closed bottle placed in an oven at $37^{\circ} \mathrm{C}\left(5 \%\right.$ of humidified $\mathrm{CO}_{2}$ ). For the 6 samples (from both undoped and $10 \mathrm{Cu}-T$ series) the pH increased, reaching about 11.7 after 24 hours, proof of $\mathrm{CaO}$ dissolution. Surprisingly, almost no $\mathrm{Cu}$ ions were released, their concentration in water being less than the detection limit of the MP-AES ( 0.01 ppm). The disks were then dried and immersed again for 24 hours at $37^{\circ} \mathrm{C}$ in ultra-pure water to ensure the complete dissolution of $\mathrm{CaO}$. Then the disks were immersed in DMEM for 24 hours at $37^{\circ} \mathrm{C}$, following the same protocol. The $\mathrm{pH}$ was measured and shown to be equal to that of pure DMEM after 24 hours at $37^{\circ} \mathrm{C}$. Contrary to the treatment in water, copper ions were released in DMEM, their concentration reaching 16.7, 17.2 and 3.0 ppm respectively for $10 \mathrm{Cu}-600,10 \mathrm{Cu}-900$ and $10 \mathrm{Cu}-1200$ samples. Copper ion concentration was finally measured after a second treatment of 24 hours in DMEM, and showed a release of 3.0, 6.6 and $0.4 \mathrm{ppm}$ for $10 \mathrm{Cu}-600,10 \mathrm{Cu}-900$ and $10 \mathrm{Cu} 1200$ samples respectively, far less than the concentration obtained from the first experiment, with no post-treatment of the samples. Figure SEI4 illustrates these two experiments, and the corresponding disk preparations for the three cytotoxicity evaluation campaigns ( $0, \mathrm{~A}$ and $\mathrm{B})$.

\subsection{Cytotoxicity evaluation}

Three cytotoxicity (i.e. cell viability) evaluation campaigns were conducted: first, experiments with disks from as-synthesized pressed powder (campaign 0; $13 \mathrm{~mm}$ diameter disks obtained with $0.25 \mathrm{~g}$ of powder pressed under 1 ton using three $x \mathrm{Cu}-T$ series with $\mathrm{x}=00,10$ and 25); and second, experiments with disks post-treated by two water immersions (campaign A) and with a third DMEM immersion (campaign B). Thus, for both campaigns, the $\mathrm{pH}$ should not rise during the cytotoxicity tests and different copper ion concentrations can be tested, campaign A 
showing a higher $\mathrm{Cu}$ ion release compared to campaign $\mathrm{B}$. In addition to the $10 \mathrm{Cu}-600,10 \mathrm{Cu}-$ 900 and $10 \mathrm{Cu}-1200$ samples, post-synthesis treatments were performed on the $00 \mathrm{Cu}-600$, $00 \mathrm{Cu}-900$ and $00 \mathrm{Cu}-1200$ samples, in order to have copper-free reference samples for the cytotoxicity interpretation. Results from the three evaluation sets (described in Figure SEI4) are shown in Figure 8. For each campaign, one 24-well plate was used with all the composition/sintering temperatures in triplicate, including controls corresponding to disk-free wells. We did not note any bacterial contamination during the culture period. Control measurements were 24-well plate-dependent with viable cell count values from $7.610^{3}$ to 2.5 $10^{4}$ cells/well. In order to easily compare measurements from different campaigns, control results were normalized to 100 (then applying the same scale factor for all the measurements from the same 24-well plate; cytotoxicity values should be understood as a percentage of cell viability).

Campaign 0 with as-prepared disks evidences the dramatic impact of $\mathrm{pH}$ increase due to small amounts of free $\mathrm{CaO}$ in the sample (Figure 8a). In the presence of disks, undoped or $\mathrm{Cu}$-doped, cell viability was continuously below the control with five samples around or (largely) below $20 \%$ cell viability. Nevertheless it is complicated to advance general observations from campaign 0 . For a sintering temperature of $600^{\circ} \mathrm{C}$, copper incorporation dramatically reduces cytotoxicity from about $50 \%(00 \mathrm{Cu}-600)$ to about $5 \%(25 \mathrm{Cu}-600)$. A similar trend was observed for a sintering temperature of $900^{\circ} \mathrm{C}$, with slightly improved values (from about $65 \%$ for the $00 \mathrm{Cu}-900$ sample to about $20 \%$ for the $25 \mathrm{Cu}-900$ sample). For a sintering temperature of $1200^{\circ} \mathrm{C}$, the case was completely different, with an improvement in cell viability in the presence of copper (from about $20 \%$ for undoped $00 \mathrm{Cu}-1200$ sample to $50 \%$ for $\mathrm{Cu}$-doped samples). This toxic behavior of the disks cannot be attributed solely to the presence of lime. The amount of $\mathrm{CaO}$ increases with copper insertion for heat treatment at $600^{\circ} \mathrm{C}(1.0 \mathrm{wt} \%$ of $\mathrm{CaO}$ for 00Cu-600 against $1.5 \mathrm{wt} \%$ for $25 \mathrm{Cu}-600$; Table 1). Nevertheless, $\mathrm{CaO}$ was negligible with copper insertion at $900^{\circ} \mathrm{C}(0.2 \mathrm{wt} \%$ for $00 \mathrm{Cu}-900$ and $0 \mathrm{wt} \%$ for $(25 \mathrm{Cu}-900)$, and had 
completely disappeared from the samples at $1200^{\circ} \mathrm{C}$. Certainly the $\mathrm{CaO}$ and $\mathrm{CuO}$ combination should be considered to explain the toxicity of the disks prepared with as-synthesized powders. In fact, the first experiments on copper releases showed rapid and large copper concentrations in DMEM (more than 50 ppm, Figure 7).

Campaigns A and B still showed complex behaviors, although with better results in terms of cell viability (Figure 8b), indicating the beneficial effect of the disk post-treatments. In general, measurements from these two campaigns showed good cell viability at one week with respect to the control wells. For two samples only, the benefit of post-treatment was not observed: cell proliferation dropped for $00 \mathrm{Cu}-600$ and there was no effect for $00 \mathrm{Cu}-900$. Moreover, cell proliferation was clearly improved for the $\mathrm{Cu}$-containing samples $(10 \mathrm{Cu}-600,10 \mathrm{Cu}-900$ and 10Cu-1200). Again, the comparison between campaigns A and B does not enable obvious general guidelines to be drawn up. Campaign A seems favorable for samples $10 \mathrm{Cu}-600$ and $10 \mathrm{Cu}-1200$, whereas campaign $\mathrm{B}$ seems favorable for sample $10 \mathrm{Cu}-900$. Figure $8 \mathrm{~b}$ also highlights the favored proliferation for cells in contact with ceramics sintered at $1200^{\circ} \mathrm{C}$. It is clear from these three cytotoxicity evaluation campaigns that controlling the preparation conditions (composition, temperature and post-treatment) makes it possible to increase cell viability in the vicinity of the ceramic. As an example, cell viability doubled with the $00 \mathrm{Cu}$ 1200 ceramic post-treated by water immersion.

\section{5- Discussion}

The copper incorporation mechanism in BCP samples presents similarities with the temperature-dependent mechanism previously described in the case of Zn-doping [8-10] and Fe-doping [11]. The main outlines of the temperature variations of the two HAp and $\beta$-TCP phases are extremely similar for the first row transition metal series from $\mathrm{Mn}$ to $\mathrm{Zn}$ [12]. Whatever the sintering temperature or the amount of incorporated copper, Rietveld refinement 
did not show copper to calcium substitution in the HAp structure. Both $\mathrm{Ca} 1$ and $\mathrm{Ca} 2$ crystallographic sites of the HAp structure were tested: no copper substitution and no calcium deficiency were evidenced. This interstitial mechanism contradicts two earlier studies considering a substitution mechanism, carried out in 1989 on copper and zinc co-doped hydroxyapatite dried at $110^{\circ} \mathrm{C}$ only [35] and on copper-doped strontium substituted hydroxyapatite, heat-treated at $950^{\circ} \mathrm{C}$ [34]. The substitution mechanism was also mentioned in a recent study performed on copper-doped hydroxyapatite and fluorapatite, heat-treated at $700^{\circ} \mathrm{C}[36]$, although the indicated lattice parameters did not convincingly evince Vegard's law. On the other hand, the location of copper cations at the interstitial $2 b$ Wyckoff site, along the HAp hexagonal channel, has already been reported. Crystallographic studies based on single crystal data indicated $\mathrm{Cu}$ atoms at the $2 b$ site $(0,0,0)$ with the formation of linear oxocuprate entities $\mathrm{O}-\mathrm{Cu}-\mathrm{O}$ in the belovite structure [63] and also in the hydroxyapatite structure [37]. EXAFS analysis of our samples confirmed the two-fold coordination for copper cations, with the $\mathrm{d}_{\mathrm{Cu}-\mathrm{O}}$ interatomic distance refined at 1.91 (1) $\AA$. This value, greater than the previously determined $\mathrm{d} \mathrm{Zn}-\mathrm{O}=1.72 \AA[10]$ and $\mathrm{d}_{\mathrm{Fe}-\mathrm{O}}=1.84 \AA$ [11], is certainly overestimated because of the presence of about $10 \mathrm{wt} \%$ of $\mathrm{Cu}$-substituted $\beta$-TCP in the analyzed sample (15Cu-1200). For the lower sintering temperatures investigated in this study (below $1000^{\circ} \mathrm{C}$ ), $\mathrm{Cu}$ incorporation in the HAp phase is limited to the $\mathrm{Ca}_{10} \mathrm{Cu}_{0.05}\left(\mathrm{PO}_{4}\right)_{6}(\mathrm{OH})_{1.90} \mathrm{O}_{0.10}$ composition (Table SEI1). Heat treatment at $1100^{\circ} \mathrm{C}$ led to the refined $\mathrm{Ca}_{10} \mathrm{Cu}_{0.10(1)}\left(\mathrm{PO}_{4}\right)_{6}(\mathrm{OH})_{1.80(2)} \mathrm{O}_{0.20(2)}$ composition for the 50Cu-1100 sample (Table SEI1). The inserted metal cation amount at $1100^{\circ} \mathrm{C}$ is lower than that observed, in the same experimental conditions, for the Zn-doped series $\left(\mathrm{Ca}_{10} \mathrm{Zn}_{0.25}\left(\mathrm{PO}_{4}\right)_{6}(\mathrm{OH})_{1.50} \mathrm{O}_{0.50}[9]\right)$ or the Fe-doped series $\left(\mathrm{Ca}_{9.75} \mathrm{Fe}_{0.50}\left(\mathrm{PO}_{4}\right)_{6}(\mathrm{OH})_{1} \mathrm{O}_{1}\right.$ [11]). An increase in sintering temperature, up to $1200^{\circ} \mathrm{C}$, enables the $\mathrm{Ca}_{10} \mathrm{Cu}_{0.61(1)}\left(\mathrm{PO}_{4}\right)_{6}(\mathrm{OH})_{0.78(2)} \mathrm{O}_{1.22(2)}$ composition to be obtained (Table SEI1). Such a large amount of inserted copper is coherent with previous indications in the literature: $\mathrm{Ca}_{10} \mathrm{Cu}_{0.54}\left(\mathrm{PO}_{4}\right)_{6} \mathrm{O}_{1.72} \mathrm{H}_{\mathrm{y}}$ for a single crystal grown at $1300^{\circ} \mathrm{C}$ and slowly cooled to room 
temperature [37], and $\mathrm{Ca}_{10} \mathrm{Cu}_{0.72}\left(\mathrm{PO}_{4}\right)_{6}(\mathrm{OH})_{0.56} \mathrm{O}_{1.44}$ for a powder sintered at $1100^{\circ} \mathrm{C}$ and air quenched [38]. To increase the copper occupancy factor from about 5\% (corresponding to $\mathrm{Ca}_{10} \mathrm{Cu}_{0.10}\left(\mathrm{PO}_{4}\right)_{6}(\mathrm{OH})_{1.80} \mathrm{O}_{0.20}$ : the $\mathrm{Cu}$-poor $\mathrm{HAp}$ phase) to about $30 \%$ (corresponding to $\mathrm{Ca}_{10} \mathrm{Cu}_{0.60}\left(\mathrm{PO}_{4}\right)_{6}(\mathrm{OH})_{0.80} \mathrm{O}_{1.20}$ : the $\mathrm{Cu}$-rich HAp phase), it is necessary to apply temperatures greater than $1100^{\circ} \mathrm{C}$. Above this temperature, the $\beta$-TCP phase and a large part of the hydroxyapatite are transformed into the $\alpha$-TCP polymorph and tricopper phosphate $\mathrm{Cu}_{3}\left(\mathrm{PO}_{4}\right)_{2}$. We have shown that the copper-rich HAp phase, with composition $\mathrm{Ca}_{10} \mathrm{Cu}_{0.60}\left(\mathrm{PO}_{4}\right)_{6}(\mathrm{OH})_{0.80} \mathrm{O}_{1.20}$, is obtained during cooling by the transformation of both $\alpha$-TCP polymorph and $\mathrm{Cu}_{3}\left(\mathrm{PO}_{4}\right)_{2}$ into a new copper-rich HAp phase (Figure 4). Contrary to the case of $\mathrm{Zn}^{2+}$, oxocuprate insertion into the hexagonal channel led to an isotropic increase in the HAp unit cell volume (Figure 2). The insertion of linear O-Zn-O entities, at the same crystallographic site, induced an increase in the hexagonal $c$ lattice parameter, concomitant with a decrease in the basal $a$ lattice parameter [8-10], whereas we observe here a simultaneous increase in both the $a$ and $c$ lattice parameters of HAp. The comparison of $\mathrm{Zn}$-doping and $\mathrm{Cu}$-doping with equivalent doping levels shows relatively equivalent $c$ values and very different $a$ values: $a=$ $9.4305 \AA$ and $c=6.8959 \AA\left(\mathrm{V}=531.12 \AA^{3}\right)$ for $\mathrm{Ca}_{10} \mathrm{Cu}_{0.27(1)}\left(\mathrm{PO}_{4}\right)_{6}(\mathrm{OH})_{1.46(2)} \mathrm{O}_{0.54(2)}(\mathrm{Table}$ SEI1) against $a=9.4077 \AA$ and $c=6.9077 \AA\left(\mathrm{V}=529.46 \AA^{3}\right)$ for $\mathrm{Ca}_{10} \mathrm{Zn}_{0.26(1)}\left(\mathrm{PO}_{4}\right)_{6}(\mathrm{OH})_{1.48(2)} \mathrm{O}_{0.52(2)}$ [8]. The a lattice parameter of undoped HAp is intermediate, about $9.420 \AA$ (Table SEI1). It indicates that O-Zn-O attracts adjacent phosphate groups, and this is not the case with the oxocuprate entity. Phosphate anions are localized at $2.96 \AA$ from the inserted copper cations (through the O3 crystallographic site) while this distance is reduced to $2.92 \AA$ in the case of zinc cations. In a manner similar to the $\mathrm{Zn}$-doping case, $\beta$-TCP was stabilized for heat treatments at around $700^{\circ} \mathrm{C}$. About $17 \mathrm{wt} \%$ of $\beta$-TCP is observed at $700^{\circ} \mathrm{C}$ (Table 1) with the formation of a $\mathrm{Cu}$-substituted $\beta$-TCP phase with an average $\mathrm{Ca}_{2.75} \mathrm{Cu}_{0.25}\left(\mathrm{PO}_{4}\right)_{2}$ composition (Table $\mathrm{SEI} 2$ ). The substitution occurs without structural modification, in agreement with literature. A change in symmetry is reported for 
larger amounts of copper: a monoclinic $P 2_{1} / c$ structure for the $\mathrm{Ca}_{1.5} \mathrm{Cu}_{1.5}\left(\mathrm{PO}_{4}\right)_{2}$ compound [52]. The high-temperature tri-copper phosphate $\mathrm{Cu}_{3}\left(\mathrm{PO}_{4}\right)_{2}$ formed at $1100^{\circ} \mathrm{C}$ and above - which corresponds to a complete copper substitution of $\beta$-TCP, chemically speaking - has its own triclinic $P \overline{1}$ structure [53]. The Cu-rich HAp phase is formed during cooling by the transformation of both $\alpha$-TCP and $\mathrm{Cu}_{3}\left(\mathrm{PO}_{4}\right)_{2}$ phases. XANES observations, confirmed by XPS analyses, showed the presence of mixed $\mathrm{Cu}^{+} / \mathrm{Cu}^{2+}$ valence in samples heat-treated at $1100^{\circ} \mathrm{C}$ and above (Figure 6). The $\mathrm{Cu}$-rich HAp phase contains both $\mathrm{Cu}^{2+}$ and $\mathrm{Cu}^{+}$cations, and the $\mathrm{Ca}_{10} \mathrm{Cu}_{x}\left(\mathrm{PO}_{4}\right)_{6}(\mathrm{OH})_{2-2 x} \mathrm{O}_{2 x}$ general formula used does not reflect the real copper electronic state; to be exact, it should be written $\mathrm{Ca}_{10} \mathrm{Cu}^{2+}{ }_{x} \mathrm{Cu}^{+}{ }_{y}\left(\mathrm{PO}_{4}\right)_{6}(\mathrm{OH})_{2-2 x-y} \mathrm{O}_{2 x+y}$. The refined compositions indicated in Table SEI1 consider only the presence of $\mathrm{Cu}^{2+}$ cation. XPS analyses determined a $y / x$ ratio of 0.2 for the $\mathrm{Cu}$-rich $\mathrm{HAp}$ phase in the $75 \mathrm{Cu}-1200$ sample, leading to the composition $\mathrm{Ca}_{10} \mathrm{Cu}^{2+}{ }_{0.51} \mathrm{Cu}^{+}{ }_{0.10}\left(\mathrm{PO}_{4}\right)_{6}(\mathrm{OH})_{0.88} \mathrm{O}_{1.12}$. Nevertheless we should remember that XPS is strictly a surface technique, with the possibility that the bulk $y / x$ ratio can differ from the experimental 0.2 value. The mixed valence in $\mathrm{Cu}$-doped HAp was already brought to light in a previous study thanks to magnetic susceptibility measurements without the quantification of the $\mathrm{Cu}^{+} / \mathrm{Cu}^{2+}$ ratio [37]. In the case of $\mathrm{Cu}$-doped belovite, larger quantities of copper cations are inserted in the apatite hexagonal channel $\mathrm{Sr}_{10} \mathrm{Cu}_{1.70}\left(\mathrm{PO}_{4}\right)_{6} \mathrm{O}_{2} \mathrm{H}_{\mathrm{y}}$ with exclusively the $\mathrm{Cu}^{+}$electronic state for a sample annealed in argon atmosphere $[39,63]$. The authors attributed the presence of $\mathrm{Cu}^{+}$to its preference for the linear coordination compared to $\mathrm{Cu}^{2+}$.

As clearly reported in the review of Jin et al. [21], the benefits of using $\mathrm{Cu}$-doping in the development of biomaterial applications have attracted more and more attention in recent years, despite the fact that $\mathrm{Cu}$ has long been considered as toxic (when its amount exceeds certain limitations). Copper is not only an essential trace element required for human body health but it presents interesting antibacterial performances, stimulates angiogenesis, and promotes osteogenesis and the inhibition of in-stent restenosis $[20,21,33,64,65]$. The development of $\mathrm{Cu}-$ containing biomaterials with better bio-adaptation must now involve a better understanding of 
the cytotoxicity caused by the release of copper ions in physiological fluid: the dose-dependent cytotoxicity of copper [20]. We had in this study a complete set of materials to evaluate the cytotoxicity of the copper dopant with variations in 1) the HAp/ $\beta$-TCP ratio, which impacts the copper release kinetic due to the difference in solubility between the two phases, 2) the amount of incorporated copper, which impacts the level of copper release, and 3) the copper valence $\left(\mathrm{Cu}^{+}\right.$and $\left.\mathrm{Cu}^{2+}\right)$, which should impact biological behavior. First, it is essential to carry out a post-treatment on BCP sintered disks in order to suppress the high toxicity of the as-prepared samples (Figure 8a). Post-treatment is simply a washing of the disks with water, which can be combined with DMEM washing. The efficiency of these post-treatments is easily explained by the mineralogical characterization and copper location in the ceramic. The combination of the presence of free $\mathrm{CaO}$ (basic oxide, Table 1) and readily-available $\mathrm{Cu}^{2+}$ cations (either from the $\mathrm{CuO}$ phase for sintering at $600^{\circ} \mathrm{C}$, or substituted in the soluble $\beta$-TCP for sintering at $900^{\circ} \mathrm{C}$ ) explains the poor results in terms of cytotoxicity for disks pressed from as-synthesized BCP powder. The washing post-treatments enable the free basic $\mathrm{CaO}$ phase to be removed (by aqueous solubilisation) and also limit the level of copper physiological release (by a previous release in DMEM). Figure 7 evidences an almost instantaneous copper release that exceeds 10 ppm for the copper-doped samples and reaches up to $50 \mathrm{ppm}$ in three weeks. Wang et al. [20] determined a critical biological level of $\mathrm{Cu}^{2+}$ at $10 \mathrm{ppm}$. The disk washing post-treatment enables the release level to be reduced to below $10 \mathrm{ppm}$ : about $3 \mathrm{ppm}$ for $600^{\circ} \mathrm{C}$ sintering, about $7 \mathrm{ppm}$ for $900^{\circ} \mathrm{C}$ sintering and below $1 \mathrm{ppm}$ for $1200^{\circ} \mathrm{C}$ sintering. These results highlight the difference in phase solubility between the known soluble $\beta$-TCP (which is mainly present in the case of $900^{\circ} \mathrm{C}$ sintering) and the known low-solubility HAp (single doped-HAp phase samples obtained with $1200^{\circ} \mathrm{C}$ sintering). On the other hand, the presence of mixed valence $\mathrm{Cu}^{+} / \mathrm{Cu}^{2+}$ in the low soluble HAp phase does not penalize cell viability. As shown in Figure 8b, the best cell viabilities (above or close to the expected 100\%) have been measured for the $1200^{\circ} \mathrm{C}$ sintering temperature; i.e. when the mixed valence is formed (Figure 6). Finally, our 
MEB observations showed the biocompatibility with bone marrow cells; good adherence was highlighted with $\mathrm{Cu}$-doped BCP samples (Figure 9).

\section{6- Conclusion}

The present study detailed the phase composition, the copper location and the copper electronic state of a total of $36 \mathrm{Cu}$-doped BCP samples. The temperature-dependent copper incorporation mechanism was thoroughly described. The first step (at $500^{\circ} \mathrm{C}$ ) lead to $\mathrm{CuO}$ mixed with weaklydoped HAp (Cu-poor HAp). The second step, between $700^{\circ} \mathrm{C}$ and $1000^{\circ} \mathrm{C}$, corresponds to the formation of a $\mathrm{Cu}$-doped $\beta$-TCP phase mixed with the $\mathrm{Cu}$-poor $\mathrm{HAp}$. Finally, at $1100^{\circ} \mathrm{C}$ and above, samples are mainly composed of the $\mathrm{Cu}$-doped $\mathrm{HAp}$ phase $\mathrm{Ca}_{10} \mathrm{Cu}_{0.6}\left(\mathrm{PO}_{4}\right)_{6}(\mathrm{OH})_{0.8} \mathrm{O}_{1.2}$ (the Cu-rich HAp). The main features of the HAp copper doping are: 1) a low amount of metal insertion for temperatures below $1100^{\circ} \mathrm{C}$ in $\mathrm{Cu}$-poor $\mathrm{HAP} \mathrm{Ca}_{10} \mathrm{Cu}_{0.1}\left(\mathrm{PO}_{4}\right)_{6}(\mathrm{OH})_{1.8} \mathrm{O}_{0.2}$, and a higher amount for temperatures above $1100^{\circ} \mathrm{C}$ in $\mathrm{Cu}$-rich $\left.\mathrm{HAP} \mathrm{Ca} \mathrm{Ca}_{10} \mathrm{Cu}_{0.6}\left(\mathrm{PO}_{4}\right)_{6}(\mathrm{OH})_{0.8} \mathrm{O}_{1.2} ; 2\right)$ the necessity to decompose high-temperature $\mathrm{Cu}$-doped $\alpha$-TCP polymorph and $\mathrm{Cu}_{3}\left(\mathrm{PO}_{4}\right)_{2}$ to form the $\mathrm{Cu}$-rich HAp phase; and 3) the presence of the mixed $\mathrm{Cu}^{+} / \mathrm{Cu}^{2+}$ valence. Amongst our set of copper-doped BCP samples, we have several promising bioceramics for bone substitution and/or prosthesis coating. A mixture of HAp and $\beta$-TCP phases is interesting because of their difference in solubility; mixing $\mathrm{Cu}$-doped HAp and $\beta$-TCP phases enables the copper releasing kinetics to be regulated. And the presence of $\mathrm{Cu}^{+}$cations in samples heat-treated at $1100^{\circ} \mathrm{C}$ and above is potentially interesting for biomaterial applications. The ionic releases from sintered disks obtained from pressed BCP powder were observed, in order to establish a post-treatment to obtain acceptable or even very good cytotoxicity values. An understanding of the biological behavior (here in terms of cytotoxicity) and the mastery of BCP bioceramic preparation are only possible because the $\mathrm{BCP}$ doping mechanism has been clearly identified beforehand.

\section{Acknowledgements}


This work was supported by ANR under project NANOSHAP (ANR-09-BLAN-0120-03) and the CNRS 2015 PEPS project. We gratefully acknowledge SLS for the provision of synchrotron radiation facilities and we would like to thank Maarten Nachtegaal for his assistance in using the SuperXAS beamline.

\section{References}

[1] S. V. Dorozhkin, Biomater., Biocomposites and hybrid biomaterials based on calcium orthophosphates, 1 (2011) 3-56.

[2] S. G. Dahl, P. Allain, P. J. Marie, Y. Mauras, G. Boivin, P. Ammann, Y. Tsouderos, P. D. Delmas and C. Christiansen, Bone, Incorporation and distribution of strontium in bone, 28 (2001) 446-453.

[3] R. Lagier and C. A. Baud, Pathol. Res. Pract., Magnesium whitlockite, a calcium phosphate crystal of special interest in pathology, 199 (2003) 329-335.

[4] R. S. Lee, M. V. Kayser and S. Y. Ali, J. Anat., Calcium phosphate microcrystal deposition in the human intervertebral disc, 208 (2006) 13-19.

[5] C. Rey, C. Combes, C. Drouet and M. J. Glimcher, Osteoporos Int., Bone mineral: update on chemical composition and structure, 20 (2009) 1013-1021.

[6] S. Cazalbou, C. Combes, D. Eichert and C. Rey, J. Mater. Chem., Adaptative physicochemistry of bio-related calcium phosphates, 14 (2004) 2148-2153.

[7] J. C. Elliot, Structure and chemistry of the apatite and other calcium orthophosphates, Amsterdam: Elsevier, 1994.

[8] S. Gomes, J.-M. Nedelec, E. Jallot, D. Sheptyakov and G. Renaudin, Chem. Mater., Structural characterization and biological fluid interaction of solgel-derived Mg-substituted biphasic calcium phosphate ceramics, 23 (2011) 3072-3085.

[9] S. Gomes, J.-M Nedelec and G. Renaudin, Acta Biomater., On the effect of temperature on the insertion of zinc into hydroxyapatite, 8 (2012) 1180-1189. 
[10] S. Gomes, A. Kaur, J.-M Nedelec and G. Renaudin, J. Mater. Chem. B, X-ray Absorption Spectroscopy shining (synchrotron) light onto the insertion of $\mathrm{Zn}^{2+}$ in calcium phosphate ceramics and its influence on their behaviour in biological conditions, 2 (2014) 536-545.

[11] S. Gomes, A. Kaur, J.-M. Grenèche, J.-M. Nedelec and G. Renaudin, Acta Biomater., Atomic scale modeling of iron-doped biphasic calcium phosphate bioceramics, 50 (2017) 7888.

[12] G. Renaudin, S. Gomes and J.-M. Nedelec, Materials, First-row transition metal doping in calcium phosphate bioceramics: a detailed crystallographic study, 10 (2017) 92-113.

[13] Z. Radovanovic, B. Jokic, D. Veljovic, S. Dimitrijevic, V. Kojic, R. Petrovic and D. Janackovic, Appl. Surf. Sci., Antimicrobial activity and biocompatibility of $\mathrm{Ag}^{+}-$and $\mathrm{Cu}^{2+}-$ doped biphasic hydroxyapatite/ $\alpha$-tricalcium phosphate obtained from hydrothermally synthesized $\mathrm{Ag}^{+}$- and $\mathrm{Cu}^{2+}$-doped hydroxyapatite, 307 (2014) 513-519.

[14] D. H. Nies, Appl. Microbiol. Biotechnol, Microbial heavy-metal resistance, 51 (1999) 730750.

[15] H. G. Petering, Pharmacol. Ther. A, Pharmacology and toxicology of heavy metals: Silver, 1 (1976) 127-130.

[16] W. J. Schreurs and H. Rosenberg, J. Bacteriol., Effect of silver ions on transport and retention of phosphate by Escherichia coli, 152 (1982) 7-13.

[17] R. O. Darouiche, Clin. Infect. Dis., Anti-infective efficacy of silver-coated medical prostheses, 29 (1999) 1371-1377.

[18] G. Borkow and J. Gabbay, Curr. Med. Chem., Copper as a biocidal tool, 12 (2005) 21632175.

[19] Q. L. Feng, J. Wu, G. Q. Chen, F. Z. Cui, T. N. Kim and J. O. Kim, J. Biomed. Mater. Res., A mechanistic study of the antibacterial effect of silver ions on Escherichia coli and Staphylococcus aureus, 52 (2000) 662-668. 
[20] X. Wang, F. Cheng, J. Liu, J.-H. Smatt, D. Gepperth, M. Lastusaari, C. Xu and L. Hupa, Acta Biomaterialia, Biocomposites of copper-containing mesoporous bioactive glass and nanofibrillated cellulose: Biocompatibility and angiogenic promotion in chronic wound healing application, 46 (2016) 286-298.

[21] S. Jin, L. Ren and K. Yang, J. Mater. Sci. Tech., Bio-functional Cu containing biomaterials: a new way to enhance bio-adaption of biomaterials, 32 (2016) 835-839.

[22] B. R. Stern, J. Toxicol. Environ. Health Part A, Essentiality and Toxicity in Copper Health Risk Assessment: Overview, Update and Regulatory Considerations, 73 (2010) 114-127.

[23] M. Hunt, Curr. Opin. Orthop., Copper and boron as examples of dietary trace elements important in bone development and disease, 9 (1998) 28-36.

[24] H. Opsahl, Zeroniam, M. Ellison, D. Lewis, R. B. Rucker and R. S. Riggins, J. Nutr., Role of copper in collagen cross-linking and its influence on selected mechanical properties of chick bone and tendon, 112 (1982) 708-716.

[25] N. M. Lowe, W. D. Fraser and M. J. Jackson, Proc. Nutr. Soc., Is there a potential therapeutic value of copper and zinc for osteoporosis?, 61 (2002) 181-185.

[26] C. Wu, Y. Zhou, M. Xu, P. Han, L. Chen, J. Chang and Y. Xiao, Biomater., Coppercontaining mesoporous bioactive glass scaffolds with multifunctional properties of angiogenesis capacity, osteostimulation and antibacterial activity, 34 (2013) 422-433.

[27] E. A. Neel, I. Ahmed, J. Prattern, S. N. Nazhat and J. C. Knowles, Biomater., Characterisation of antibacterial copper releasing degradable phosphate glass fibres, 26 (2005) $2247-2254$

[28] S. Jaiswal, P. McHale and P. Duffy, Collloids Surf B Biointerfaces, Preparation and rapid analysis of antibacterial silver, copper and zinc doped sol-gel surfaces, 94 (2012) 170-176.

[29] G. F. Hu, J. Cell. Biochem., Copper stimulates proliferation of human endothelial cells under culture, 69 (1998) 326-335. 
[30] C. K. Sen, S. Khanna, M. Venojarvi, P. Trikha, E. C. Ellison and T. K. Hunt, Am. J. Physiol

Heart Circ. Physiol., Copper-induced vascular endothelial growth factor expression and wound healing, 282 (2002) H1821-1827.

[31] M. Frangoulis, P. Georgiou, C. Chrisostomidis, D. Perrea, I. Dontas and N. Kavantzas, Plast. Reconstr. Surg., Rat Epigastric Flap Survival and VEGF Expression after Local Copper Application, 119 (2007) 837-843.

[32] A. Ewald, C. Kappel, E. Vorndran, C. Moseke, M. Gelinsky and U. Gbureck, J. Biomed. Mater. Res. Part A, The effect of Cu(II)-loaded brushite scaffolds on growth and activity of osteoblastic cells, 100 (2012) 2392-2400.

[33] R. A. Popescu, K. Magyari, A. Vulpoi, D. L. Trandafir, E. Licarete, M. Todea, R. Stefan, C. Voica, D. C. Vodnar, S. Simon, I. Papuc and L. Baia, Biomater. Sci., Bioactive and biocompatible copper containing glass-ceramics with remarkable antibacterial properties and high cell viability designed for future in vivo trials, 4 (2016) 1252-1265.

[34] M. Pujari and P. N. Patel, J. Solid State Chem., Strontium-copper-calcium hydroxyapatite solid solutions: Preparation, infrared, and lattice constant measurements, 83 (1989) 100-104.

[35] N. K. Triphathy, P. N. Patel and A. Panda, J. Solid State Chem., Preparation, IR, and lattice constant measurements of mixed $(\mathrm{Ca}+\mathrm{Cu}+\mathrm{Zn})$ hydroxylapatites, 80 (1989) 1-5.

[36] S. Shanmugam and B. Gopal, Ceram. Int., Copper substituted hydroxyapatite and fluorapatite: Synthesis, characterization and antimicrobial properties, 40 (2014) 15655-15662.

[37] A. S. Karpov, J. Nuss, M. Jansen, P. E. Kazin and Y. D. Tretyakov, Solid State Sci., Synthesis, crystal structure and properties of calcium and barium hydroxyapatites containing copper ions in hexagonal channels, 5 (2003) 1277-1283.

[38] T. Baikie, G. M. H. Ng, S. Madhavi, S. P. Pramana, K. Blake, M. Elcombe and T. J. White, Dalton Trans., The crystal chemistry of the alkaline-earth apatites $\mathrm{A}_{10}\left(\mathrm{PO}_{4}\right)_{6} \mathrm{Cu}_{\mathrm{x}} \mathrm{O}_{\mathrm{y}}(\mathrm{H})_{\mathrm{z}}(\mathrm{A}=$ $\mathrm{Ca}, \mathrm{Sr}$ and Ba), 34 (2009) 6722-6726. 
[39] F. E. Imrie, J. M. S. Skakle and I. R. Gibson, Bioceram. Dev. Appl., Preparation of CopperDoped Hydroxyapatite with Varying $\mathrm{x}$ in the Composition $\mathrm{Ca}_{10}\left(\mathrm{PO}_{4}\right)_{6} \mathrm{Cu}_{\mathrm{x}} \mathrm{O}_{\mathrm{y}} \mathrm{H}_{z}$, (2013) $\mathrm{S} 1: 005$, doi: 10.4172/2090-5025.S1-005

[40] J. Rodriguez-Carvajal, PROGRAM FullProf.2k-version 3.20; Laboratoire Léon Brillouin (CEA-CNRS): Saclay, France, 2005; FullProf.2k manual available on http://www-

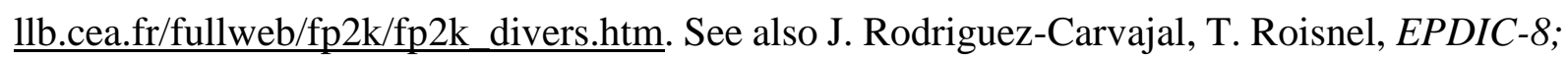
May 23-26, 2002; Trans. Tech. Publication: Uppsala, Sweden; Mater. Sci. Forum 2004; $123: 443$.

[41] N. Newville, J. Synchrotron Rad., IFEFFIT : interactive XAFS analysis and FEFF fitting, 8 (2001) 322-324.

[42] B. Ravel, J. Synchrotron Rad., ATOMS: crystallography for the X-ray absorption spectroscopist, 8 (2001) 314-316.

[43] J. J. Rehr, J. Mustre de Leon, S. I. Zabinsky and R. C. Albers, J Am Chem Soc, Theoretical X-ray absorption fine structure standards, 113 (1991) 5135-5145.

[44] D. Shirley, Phys. Rev. B, High-Resolution X-Ray Photoemission Spectrum of the Valence Bands of Gold, 5 (1972) 4709-4714.

[45] J. Scofield, J. Electron Spectrosc. Relat. Phenom., Hartree-Slater subshell photoionization cross-sections at 1254 and $1487 \mathrm{eV}, 8$ (1976) 129-137.

[46] G. Renaudin, P. Laquerrière, Y. Filinchuk, E. Jallot and J.-M. Nedelec, J. Mater. Chem., Structural characterization of sol-gel derived Sr-substituted calcium phosphates with antiosteoporotic and anti-inflammatory properties, 18 (2008) 3593-3600.

[47] G. Renaudin, E. Jallot and J.-M. Nedelec, J. Sol-Gel Sci. Technol., Effect of strontium substitution on the composition and microstructure of sol-gel derived calcium phosphate, 51 (2009) 287-294. 
[48] S. Gomes, G. Renaudin, E. Jallot and J.-M. Nedelec, Appl. Mater. Interfaces, Structural characterization and biological fluid interaction of sol-gel derived Mg-substituted biphasic calcium phosphate ceramics, 1 (2009) 505-513.

[49] L. M. Rodriguez-Lorenzo, J. N. Hart and A. Gross, J. Phys. Chem. B, Structural and Chemical Analysis of Well-Crystallized Hydroxyfluorapatites, 107 (2003) 8316-8320.

[50] M. Yashima, A. Sakai, T. Kamiyama and A. Hoshikawa, J. Solid State Chem., Crystal structure analysis of $\beta$-tricalcium phosphate $\mathrm{Ca}_{3}\left(\mathrm{PO}_{4}\right)_{2}$ by neutron powder diffraction, 175 (2003) 272-277.

[51] B. I. Lazoryak, N. Khan, V. A. Morozov, A. A. Belik and S. S. Khasanov, J. Solid State Chem., Preparation, structure determination, and redox characteristics of new calcium copper phosphates, 145 (1999) 345-355.

[52] V. Yu. Pomjakushin, A. Furrer, D. V. Sheptyakov, E. V. Pomjakushina and K. Conder, Phys. Rev. B, Crystal and magnetic structures of the spin-trimer compounds $\mathrm{Ca}_{3} \mathrm{Cu}_{3-\mathrm{x}} \mathrm{Ni}_{\mathrm{x}}\left(\mathrm{PO}_{4}\right)_{4}$ $(\mathrm{x}=0,1,2), 76(2007) 174433-174439$.

[53] G. L. Shoemaker, J. B. Anderson and E. Kostiner, Acta Crystallogr. Sect. B: Sturct. Sci, Copper(II) phosphate, 33 (1977) 2969-2972.

[54] S. P. Cramer and K. O. Hodgson, Prog. Inorg. Chem., X-ray absorption spectroscopy: a new structural method and its applications to bioinorganic chemistry, 25 (1979) 1-39.

[55] P. A. Lee, P. H. Citrin, P. Eisenberger, B. M. Kincaid, Rev. Mod. Phys., Extended X-ray absorption fine structure - its strengths and limitations as a structural tool, 53 (1981) 769-806. [56] E. I. Solomon, In Comments of Inorganic Chemistry; Sutin, Norman, Ed.; Gordon \& Breach: New York, 1984; Vol. 3, pp 225-320.

[57] L.S Kau, D.J. Spria-Solomon, J.E. Penner-Hahn, K.O. Hodgson and E.I. Solomon, J. Am. Chem. Soc., X-ray absorption edge determination of the oxidation state and coordination number of copper. Application to the type 3 site in Rhus vernicifera laccase and its reaction with oxygen, 109 (1987) 6433-6442. 
[58] A. Gaur, B. D. Shrivastava and S. K. Joshi, $14^{\text {th }}$ International Conference on X-Ray Absorption Fine Structure (XAF14) journal of Physics: Conference series 190, 2009, 012084. [59] L. Martin, H. Martinez, D. Poinot, B. Pecquenard and F. Le Cras, J. Phys. Chem. C, Comprehensive X-ray photoelectron spectroscopy study of the conversion reaction mechanism of $\mathrm{CuO}$ in lithiated thin film electrodes, 117 (2013) 4421-4430.

[60] S. Harmer, W. Skinner, A. Buckley, and L.-J. Fan, Surf. Sci., Species formed at cuprite fracture surfaces; observation of O 1s surface core level shift, 603 (2009) 537-545.

[61] F. Parmigiani, L. Depero, T. Minerva, and J. Torrance, J. Electron Spectrosc. Relat. Phenom., The fine structure of the $\mathrm{Cu} 2 \mathrm{p}_{3 / 2} \mathrm{X}$-ray photoelectron spectra of copper oxide based compounds, 58 (1992) 315-323.

[62] F. Parmigiani, G. Pacchioni, F. Illas, and P. Bagus, J. Electron Spectrosc. Relat. Phenom., Studies of the $\mathrm{Cu}-\mathrm{O}$ bond in cupric oxide by $\mathrm{X}$-ray photoelectron spectroscopy and ab initio electronic structure models, 59 (1992) 255-269.

[63] P. E. Kazin, A. S. Karpov, J. Martin, J. Nuss and Y. D. Tretyakov, Z. Anorg. Allg. Chem., Crystal structure and properties of strontium phosphate apatite with oxocuprate ions in hexagonal channels, 629 (2003) 344-3520.

[64] V. Stanic, S. Dimitrijevic, J. A. Stankovic, M. Mitric, B. Jokic, I. B. Plecas and S. Raicevic, Appl. Surf. Sci., Synthesis, characterization and antimicrobial activity of copper and zinc-doped hydroxyapatite nanopowders, 256 (2010) 6083-6089.

[65] N. Matsumoto, K. Sato, K. Yoshida, K. Hashimoto and Y. Toda, Acta Biomater., Preparation and characterization of $\beta$-tricalcium phosphate co-doped with monovalent and divalent antibacterial metal ions, 5 (2009) 3157-3164. 


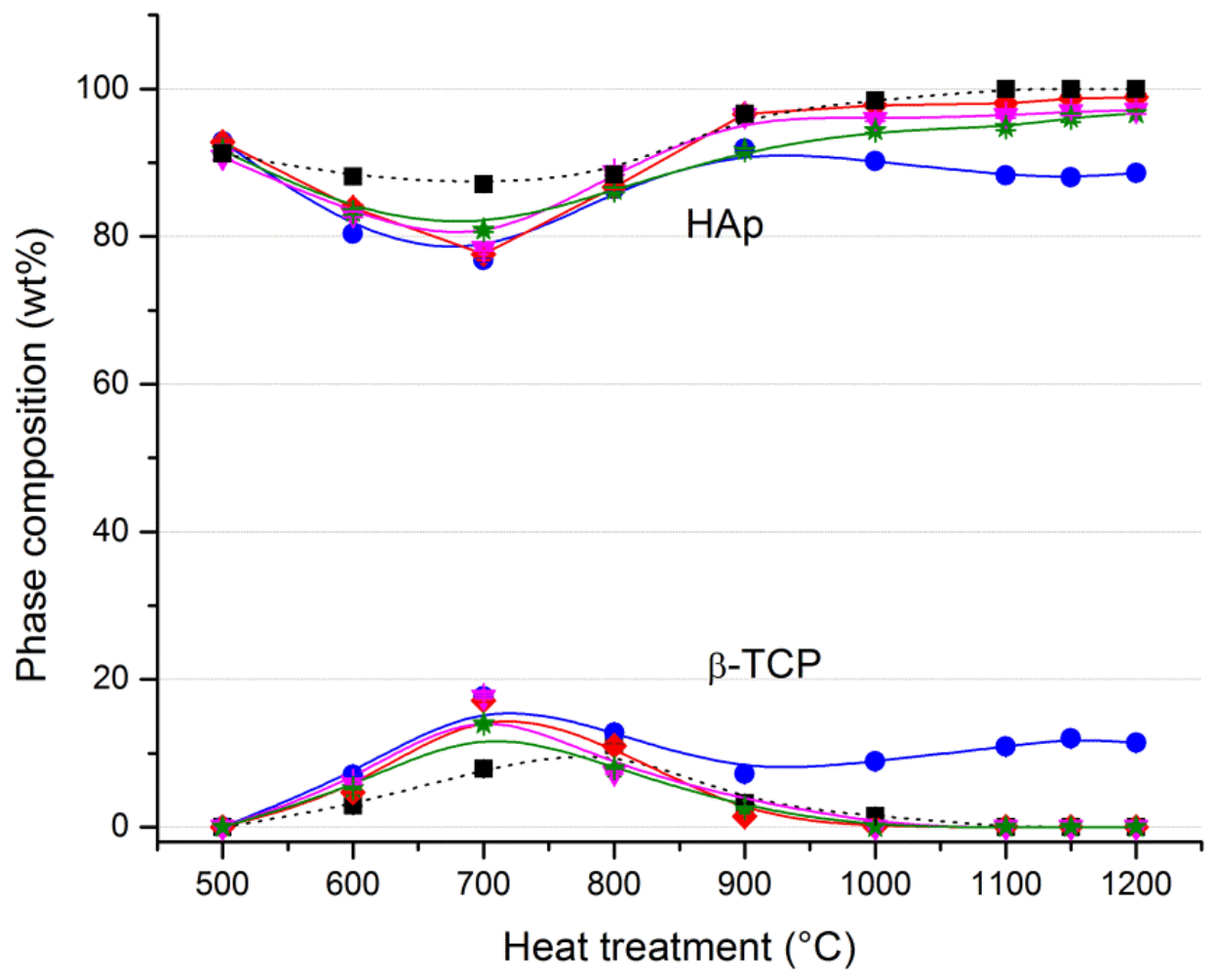

Figure 1. Mineral composition of the two main phases (HAp and $\beta$-TCP) as a function of sintering temperature for the five series: undoped (black squares, dotted lines), $15 \mathrm{Cu}-\mathrm{T}$ (blue circles, solid lines), 25Cu-T (red diamonds, solid lines), 50Cu-T (pink triangles, solid lines) and 75Cu-T (green stars, solid lines). 

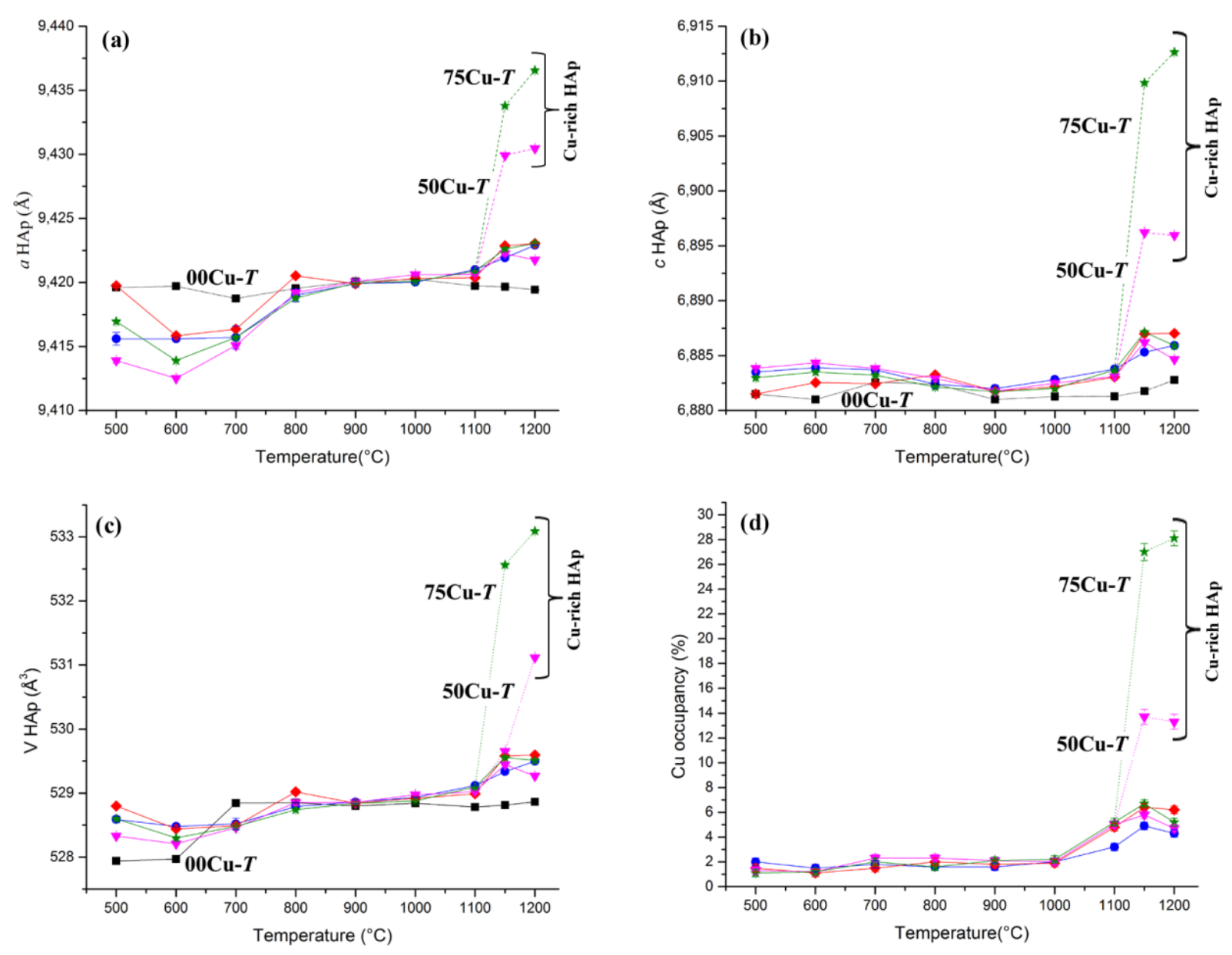

Figure 2. Thermal variations in HAp lattice parameters: (a) lattice parameters a, (b) lattice parameter c, (c) unit cell volume, and (d) the $\mathrm{Cu}$ occupancy factor attributed to the $2 \mathrm{~b}$ Wyckoff site $(0,0,0)$. The undoped series $00 \mathrm{Cu}$ $\mathrm{T}$ (black squares), and the $\mathrm{Cu}$-doped series $15 \mathrm{Cu}-\mathrm{T}$ (blue circles), $25 \mathrm{Cu}-\mathrm{T}$ (red diamonds), 50Cu- $\mathrm{T}$ (pink triangles and $75 \mathrm{Cu}-\mathrm{T}$ (green stars) are represented. Solid lines correspond to variation in the undoped and $\mathrm{Cu}$-poor HAp (i.e. HAp1 in Tables 1 and 2) phases, whereas dotted lines correspond to the Cu-rich HAp (i.e. HAp2 in Tables 1 and 2) phase resolved in the two $50 \mathrm{Cu}-\mathrm{T}$ and $75 \mathrm{Cu}-\mathrm{T}$ series. 


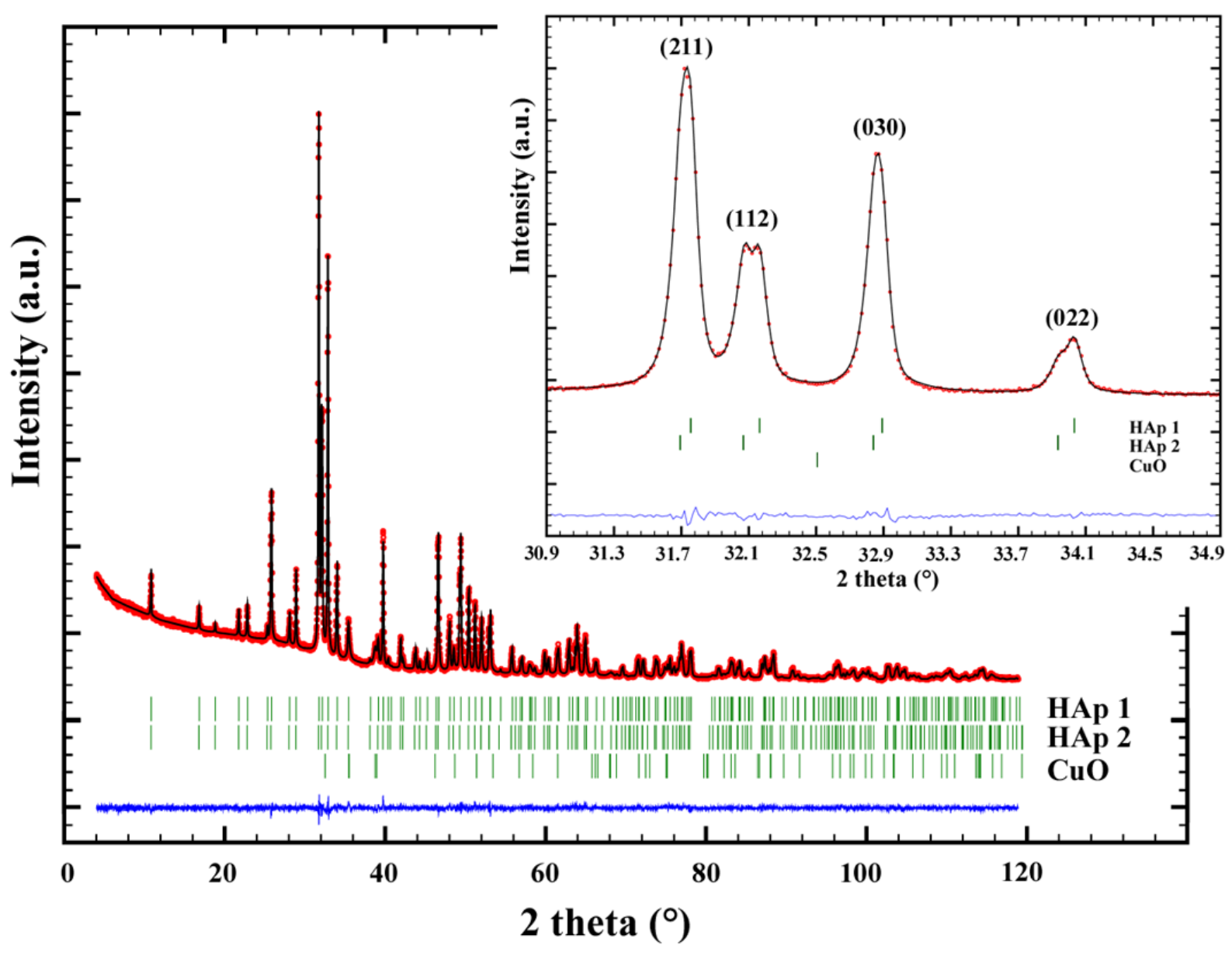

Figure 3. Rietveld refinement performed on $75 \mathrm{Cu}-1200$ pattern recorded in transmission mode, showing the presence of two HAp phases: HAp1 for the Cu-poor HAp phase and HAp2 for the Cu-rich HAp phase. Inset shows the 2-theta resolution conveyed by transmission geometry. 


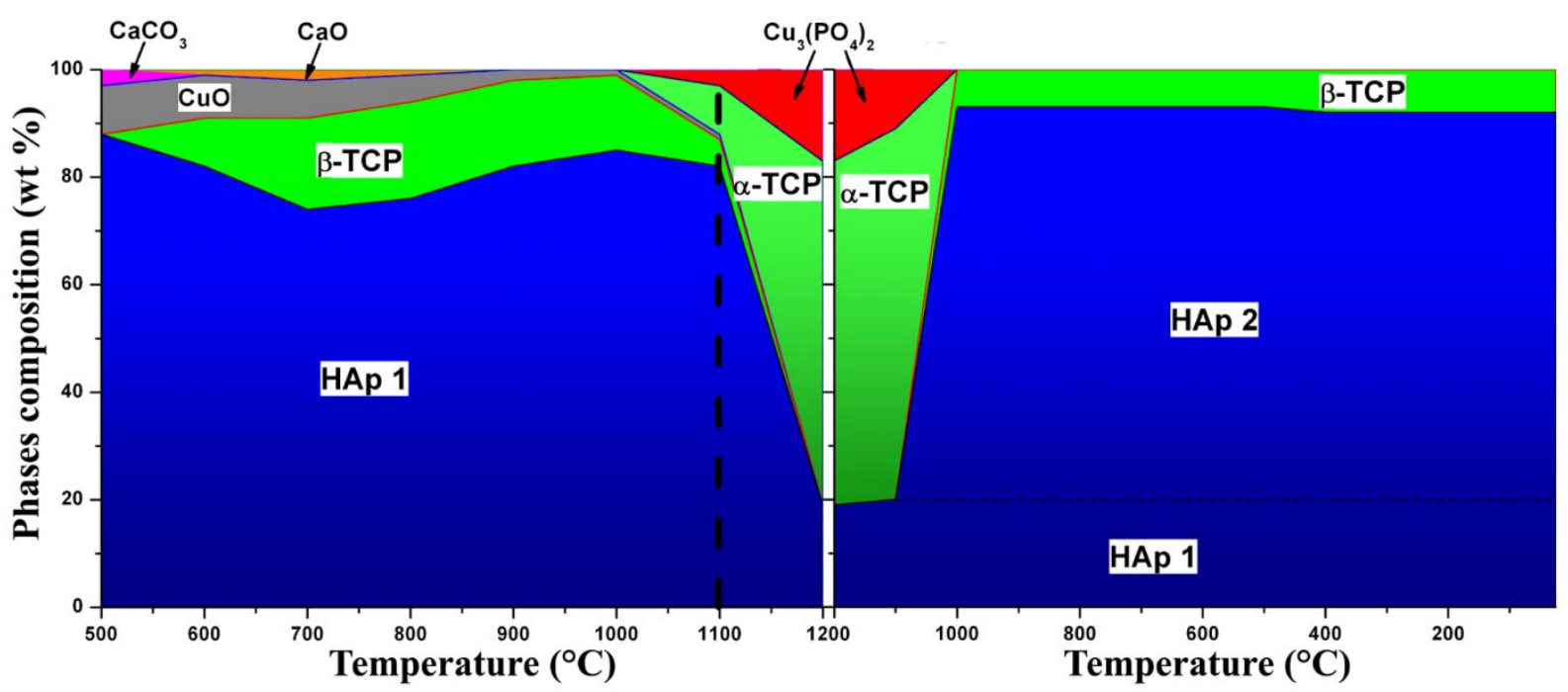

Figure 4. Temperature phase evolution extracted from Rietveld refinements performed on in-situ XRPD measurements using a HTK chamber on the $75 \mathrm{Cu}-T$ series. 

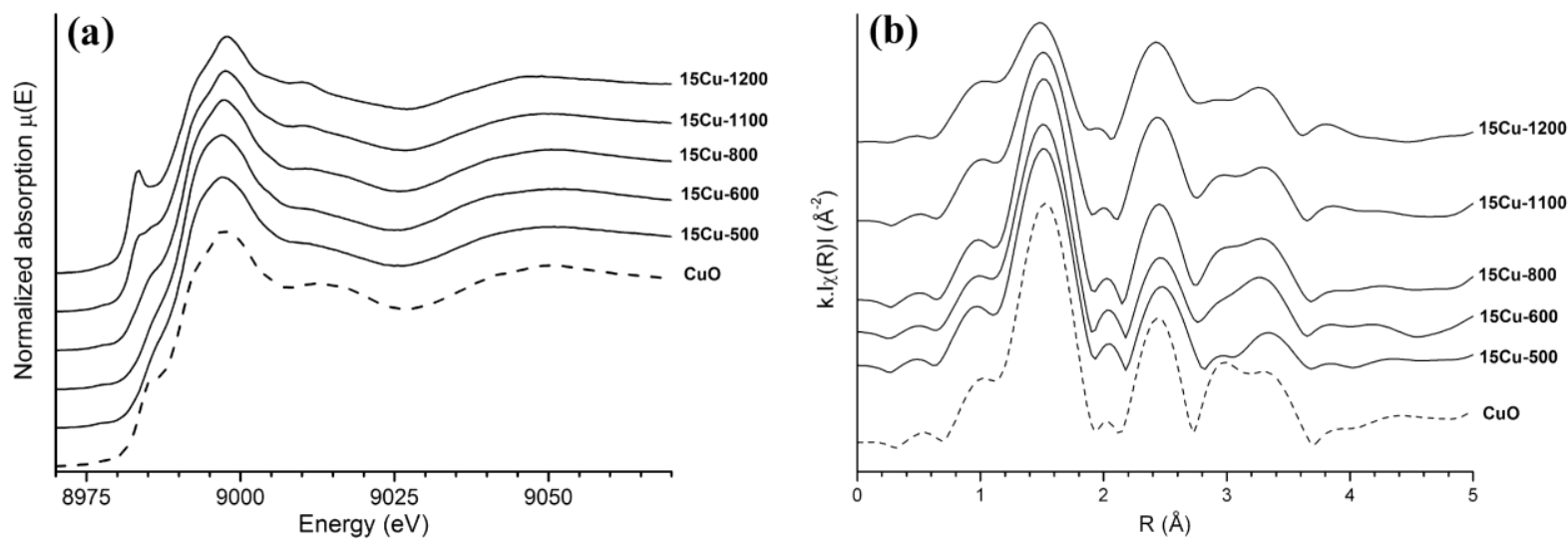

Figure 5. (a) XANES part of the XAS spectra, and (b) k-weighted amplitudes of the Fourier transform, uncorrected for phase shift, for the $15 \mathrm{Cu}-\mathrm{T}$ series samples (solid lines) and the reference compound ( $\mathrm{CuO}$, dashed lines). 


\section{Cu $2 p_{3 / 2}$}

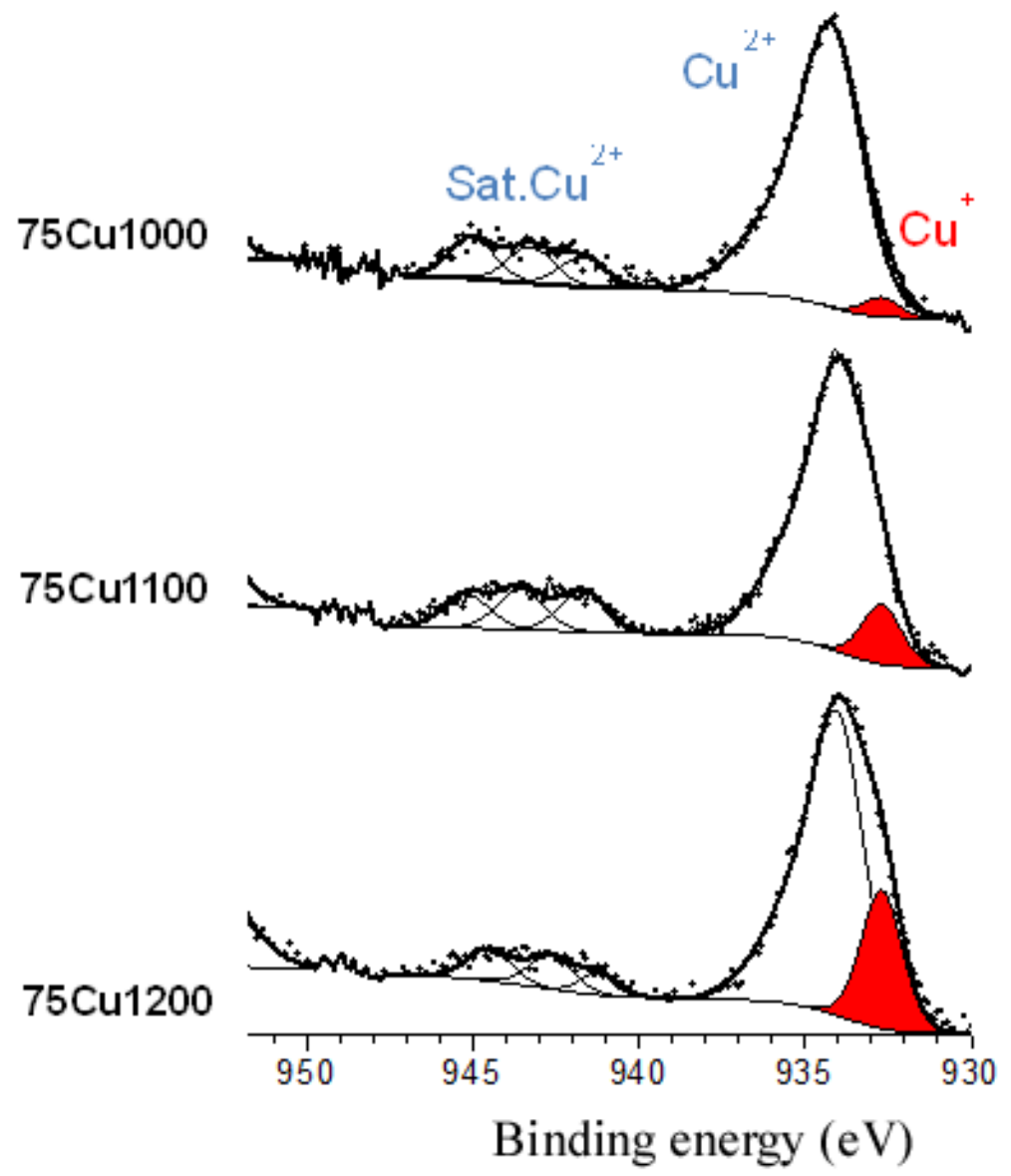

Figure 6. $\mathrm{Cu} 2 \mathrm{p}_{3 / 2} \mathrm{XPS}$ core peak of three samples from the $75 \mathrm{Cu}-\mathrm{T}$ series (from $1000^{\circ} \mathrm{C}$ to $1200^{\circ} \mathrm{C}$ ). 


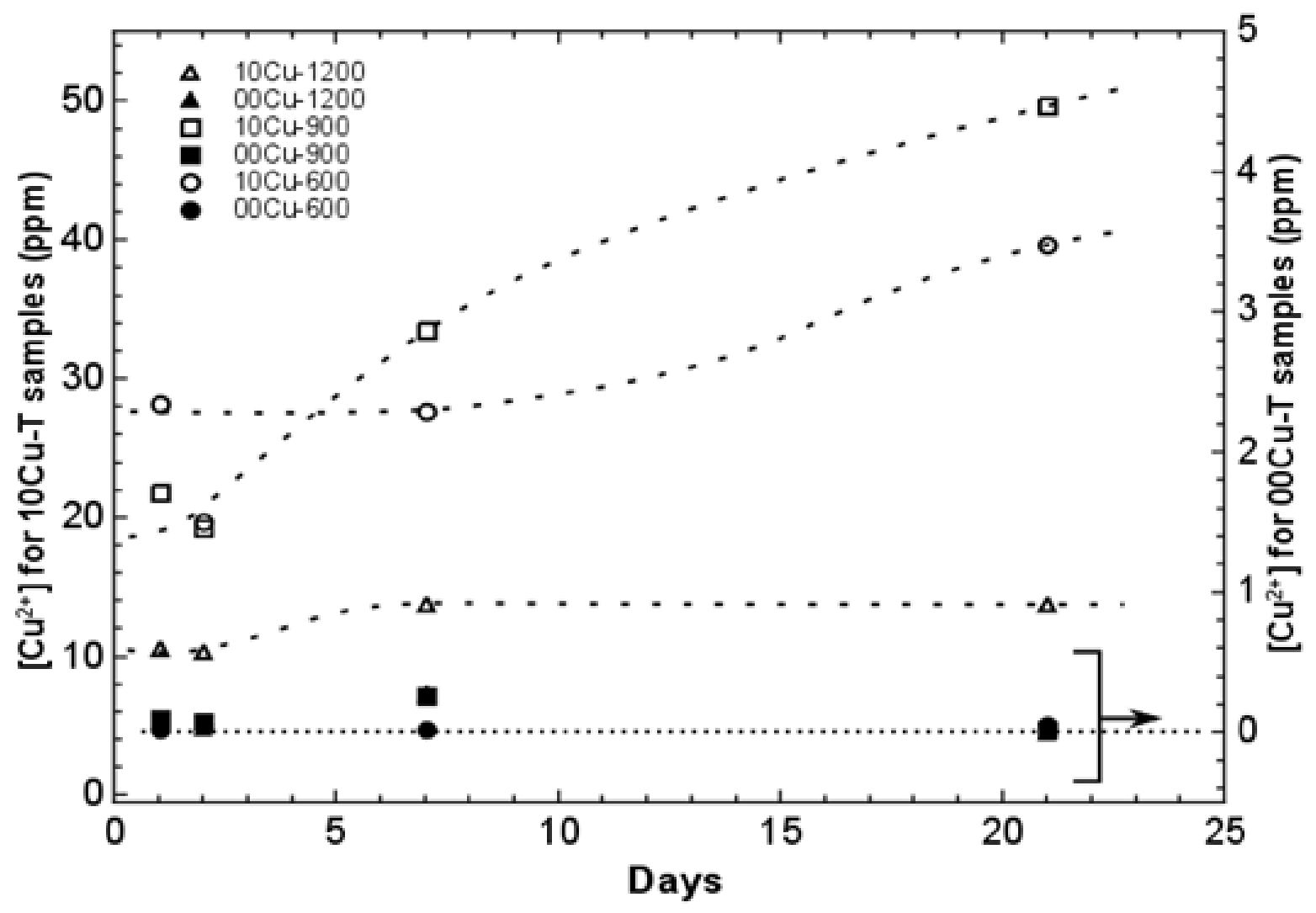

Figure 7. Copper ion concentration in DMEM versus disk immersion time at $37^{\circ} \mathrm{C}$ for undoped and $10 \mathrm{Cu}-\mathrm{T}$ samples annealed at 600,900 and $1200^{\circ} \mathrm{C}$. 

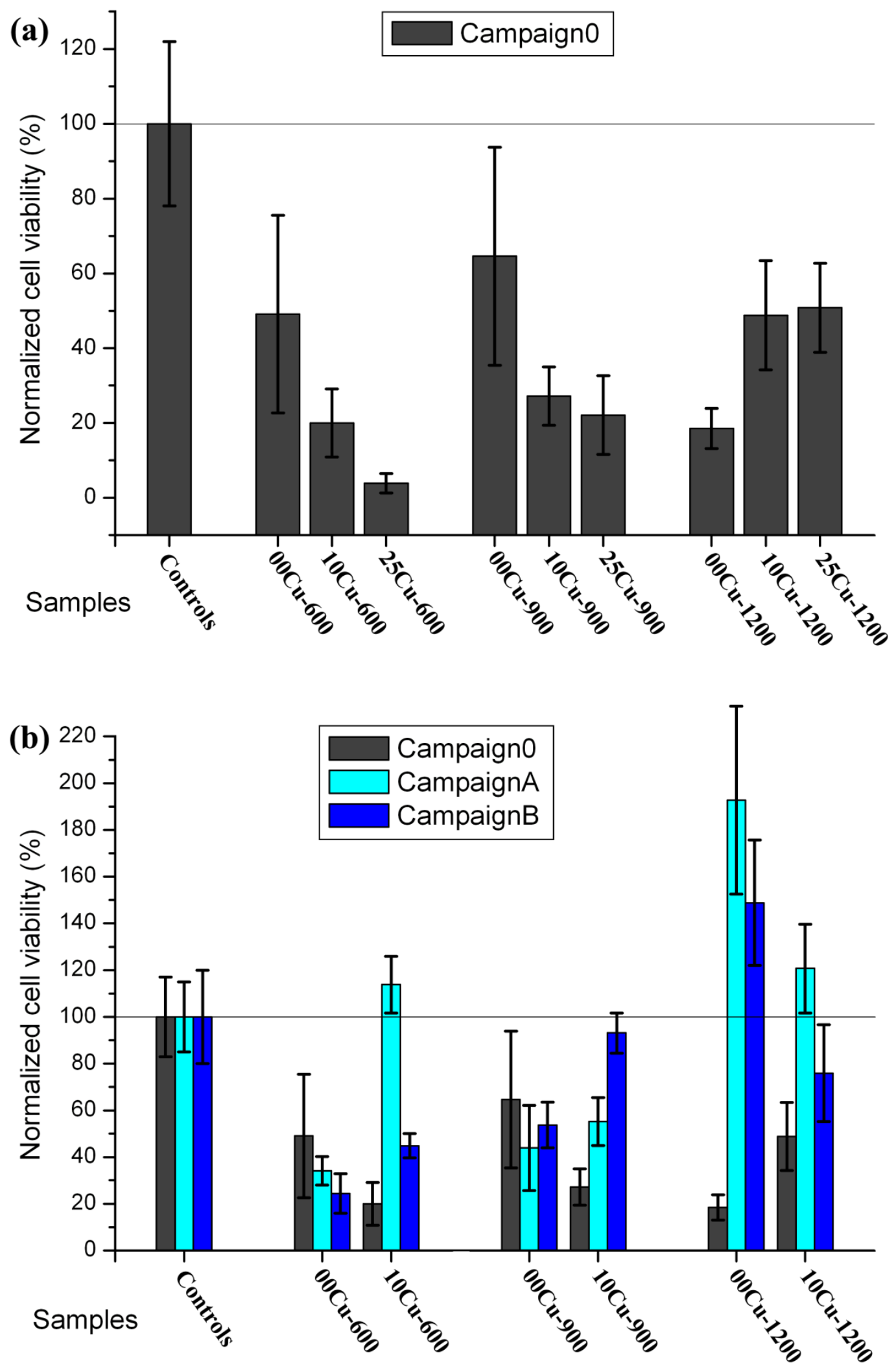

Figure 8. Cell viability evaluation for a) Series 0 for $\mathrm{xCu}-\mathrm{T}$ samples with $\mathrm{x}=00,10$ and 20; and b) with Series $\mathrm{A}$ and $\mathrm{B}$ for $\mathrm{xCu}-\mathrm{T}$ samples with $\mathrm{x}=00$ and 10 . Error bars represent the standard error of mean from triplicate samples. 


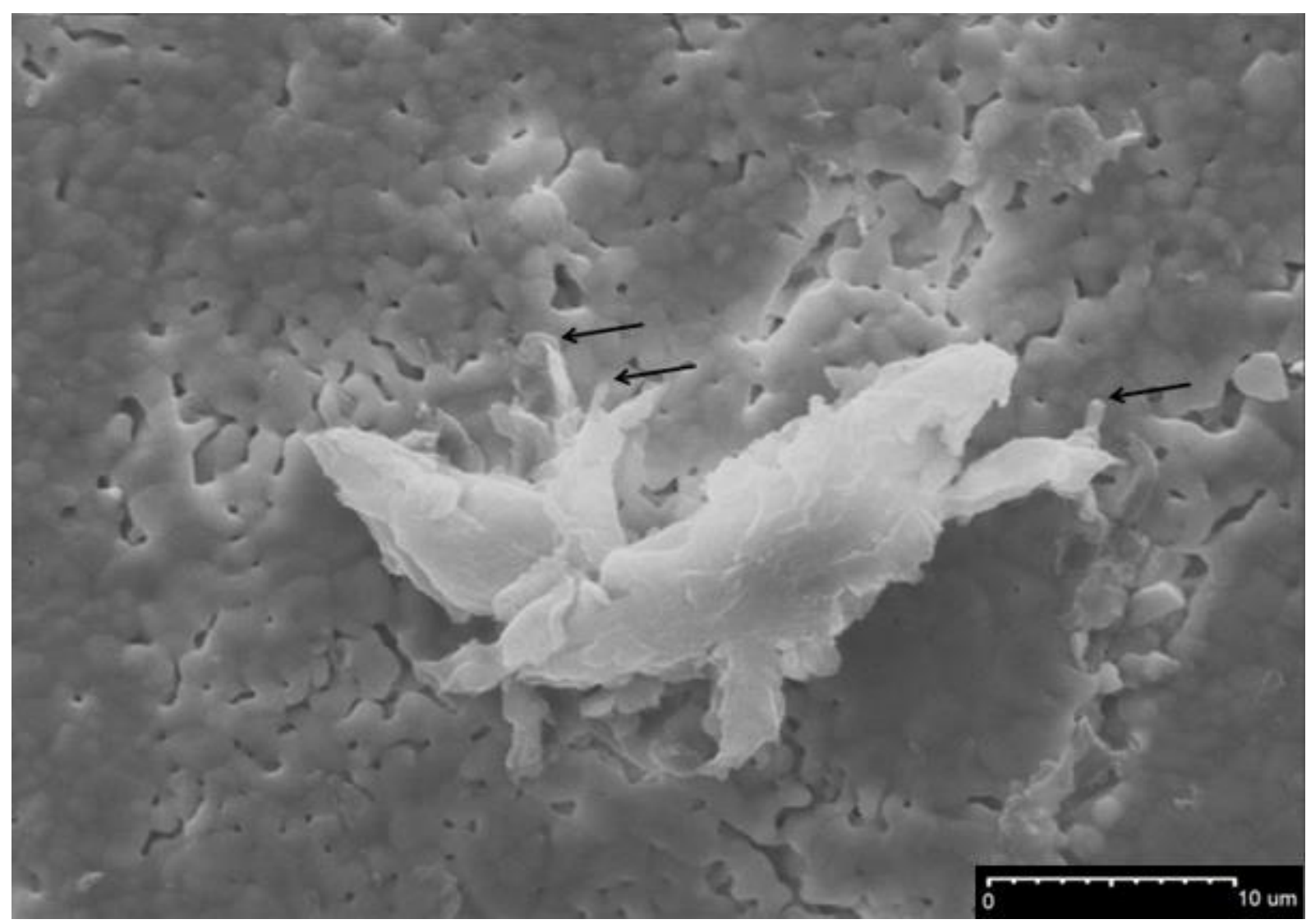

Figure 9. Bone marrow adherent cell after 8 days of culture on a $10 \mathrm{Cu}-600$ ceramic disk. These cells develop a strong attachment to the material surface through cellular expansion (black arrows). 
Table 1. Results of quantitative analyses (wt \%) extracted from Rietveld refinements for the undoped BCP series and the $\mathrm{Cu}$-doped BCP series. Standard deviations are indicated in parentheses.

\begin{tabular}{|c|c|c|c|c|c|c|c|}
\hline \multirow{2}{*}{ Samples } & & \multicolumn{6}{|c|}{ Mineralogical composition (wt \%) } \\
\hline & HAp1 & HAp2 & $\beta$-ТCP & $\alpha-\mathrm{CDP}$ & $\mathrm{CaCO}_{3}$ & $\mathrm{CaO}$ & $\mathrm{CuO}$ \\
\hline $\begin{array}{l}00 \mathrm{Cu}-500 \\
00 \mathrm{Cu}-600 \\
00 \mathrm{Cu}-700 \\
00 \mathrm{Cu}-800 \\
00 \mathrm{Cu}-900 \\
00 \mathrm{Cu}-1000 \\
00 \mathrm{Cu}-1100 \\
00 \mathrm{Cu}-1150 \\
00 \mathrm{Cu}-1200\end{array}$ & $\begin{array}{l}91.2(9) \\
88.1(9) \\
87.1(9) \\
88.4(9) \\
96.6(6) \\
98.4(9) \\
100(-) \\
100(-) \\
100(-)\end{array}$ & $\begin{array}{l}- \\
- \\
- \\
- \\
- \\
- \\
- \\
- \\
-\end{array}$ & $\begin{array}{l}- \\
2.9(3) \\
7.9(3) \\
11.1(3) \\
3.2(3) \\
1.5(3) \\
- \\
- \\
-\end{array}$ & $\begin{array}{l}4.4(3) \\
7.2(3) \\
3.9(3) \\
- \\
- \\
- \\
- \\
- \\
-\end{array}$ & $\begin{array}{l}3.7(2) \\
0.9(1) \\
0.5(1) \\
- \\
- \\
- \\
- \\
- \\
-\end{array}$ & $\begin{array}{l}0.8(1) \\
1.0(1) \\
0.6(1) \\
0.5(1) \\
0.2(1) \\
0.1(1) \\
- \\
- \\
- \\
\end{array}$ & $\begin{array}{l}- \\
- \\
- \\
- \\
- \\
- \\
- \\
- \\
-\end{array}$ \\
\hline $\begin{array}{l}10 \mathrm{Cu}-600 \\
10 \mathrm{Cu}-900 \\
10 \mathrm{Cu}-1200\end{array}$ & $\begin{array}{l}88.5(9) \\
94.2(8) \\
98.6(5)\end{array}$ & $\begin{array}{l}- \\
- \\
-\end{array}$ & $\begin{array}{l}2.4(4) \\
5.8(4) \\
1.4(3)\end{array}$ & $\begin{array}{l}6.2(4) \\
- \\
- \\
\end{array}$ & $\begin{array}{l}1.1(1) \\
- \\
-\end{array}$ & $\begin{array}{l}1.8(1) \\
- \\
-\end{array}$ & $\begin{array}{l}- \\
- \\
-\end{array}$ \\
\hline $\begin{array}{l}15 \mathrm{Cu}-500 \\
15 \mathrm{Cu}-600 \\
15 \mathrm{Cu}-700 \\
15 \mathrm{Cu}-800 \\
15 \mathrm{Cu}-900 \\
15 \mathrm{Cu}-1000 \\
15 \mathrm{Cu}-1100 \\
15 \mathrm{Cu}-1150 \\
15 \mathrm{Cu}-1200\end{array}$ & $\begin{array}{l}92.9(4) \\
80.4(4) \\
76.8(3) \\
86.4(3) \\
91.9(3) \\
90.2(3) \\
88.3(3) \\
88.0(3) \\
88.6(3)\end{array}$ & $\begin{array}{l}- \\
- \\
- \\
- \\
- \\
- \\
- \\
- \\
-\end{array}$ & $\begin{array}{l}- \\
7.1(2) \\
17.7(2) \\
12.8(1) \\
7.2(1) \\
8.9(9) \\
10.9(1) \\
12.0(1) \\
11.4(1)\end{array}$ & $\begin{array}{l}2.9(1) \\
9.2(2) \\
3.4(1) \\
- \\
- \\
- \\
- \\
- \\
-\end{array}$ & $\begin{array}{l}3.1(1) \\
1.3(2) \\
0.8(1) \\
- \\
- \\
- \\
- \\
- \\
-\end{array}$ & $\begin{array}{l}0.5(1) \\
1.0(1) \\
0.9(1) \\
- \\
- \\
- \\
- \\
- \\
-\end{array}$ & $\begin{array}{l}0.6(1) \\
1.0(1) \\
0.3(1) \\
0.9(1) \\
0.9(1) \\
0.9(1) \\
0.8(1) \\
- \\
-\end{array}$ \\
\hline $\begin{array}{l}25 \mathrm{Cu}-500 \\
25 \mathrm{Cu}-600 \\
25 \mathrm{Cu}-700 \\
25 \mathrm{Cu}-800 \\
25 \mathrm{Cu}-900 \\
25 \mathrm{Cu}-1000 \\
25 \mathrm{Cu}-1100 \\
25 \mathrm{Cu}-1150 \\
25 \mathrm{Cu}-1200 \\
\end{array}$ & $\begin{array}{l}92.8(4) \\
83.9(4) \\
77.6(3) \\
86.7(3) \\
96.6(3) \\
97.8(3) \\
98.1(4) \\
98.7(4) \\
98.9(4)\end{array}$ & $\begin{array}{l}- \\
- \\
- \\
- \\
- \\
- \\
- \\
- \\
-\end{array}$ & $\begin{array}{l}- \\
4.7(1) \\
17.1(2) \\
11.0(1) \\
1.4(7) \\
- \\
- \\
- \\
-\end{array}$ & $\begin{array}{l}2.4(1) \\
8.5(2) \\
2.4(1) \\
- \\
- \\
- \\
- \\
- \\
-\end{array}$ & $\begin{array}{l}2.5(1) \\
0.3(1) \\
- \\
- \\
- \\
- \\
- \\
- \\
-\end{array}$ & $\begin{array}{l}1.3(1) \\
1.5(1) \\
1.7(1) \\
0.5(1) \\
- \\
- \\
- \\
- \\
-\end{array}$ & $\begin{array}{l}1.0(1) \\
1.0(1) \\
1.0(1) \\
1.8(1) \\
2.0(1) \\
2.2(1) \\
1.9(1) \\
1.3(1) \\
1.1(1)\end{array}$ \\
\hline $\begin{array}{l}50 \mathrm{Cu}-500 \\
50 \mathrm{Cu}-600 \\
50 \mathrm{Zn}-700 \\
50 \mathrm{Cu}-800 \\
50 \mathrm{Cu}-900 \\
50 \mathrm{Cu}-1000 \\
50 \mathrm{Cu}-1100 \\
50 \mathrm{Cu} 1150 \\
50 \mathrm{Cu} 1200 \\
\end{array}$ & $\begin{array}{l}90.8(4) \\
83.0(4) \\
78.4(3) \\
88.7(3) \\
96.4(3) \\
96.2(3) \\
96.6(3) \\
67.8(4) \\
66.5(4) \\
\end{array}$ & $\begin{array}{l}- \\
- \\
- \\
- \\
- \\
- \\
- \\
29.1(3) \\
30.6(3)\end{array}$ & $\begin{array}{l}- \\
6.0(2) \\
17.6(2) \\
7.4(2) \\
- \\
- \\
- \\
- \\
- \\
\end{array}$ & $\begin{array}{l}2.3(1) \\
6.9(1) \\
- \\
- \\
- \\
- \\
- \\
- \\
-\end{array}$ & $\begin{array}{l}2.5(1) \\
- \\
- \\
- \\
- \\
- \\
- \\
- \\
-\end{array}$ & $\begin{array}{l}0.8(1) \\
1.4(1) \\
1.2(1) \\
0.4(1) \\
- \\
- \\
- \\
- \\
- \\
\end{array}$ & $\begin{array}{l}2.9(1) \\
2.7(1) \\
2.8(1) \\
3.5(1) \\
3.6(1) \\
3.8(1) \\
3.4(1) \\
2.8(1) \\
2.7(1) \\
\end{array}$ \\
\hline $\begin{array}{l}75 \mathrm{Cu}-500 \\
75 \mathrm{Cu}-600 \\
75 \mathrm{Zn}-700 \\
75 \mathrm{Cu}-800 \\
75 \mathrm{Cu}-900 \\
75 \mathrm{Cu}-1000 \\
75 \mathrm{Cu}-1100 \\
75 \mathrm{Cu}-1100^{*} \\
75 \mathrm{Cu}-1150 \\
75 \mathrm{Cu}-1200 \\
75 \mathrm{Cu}-1200^{*}\end{array}$ & $\begin{array}{l}91.7(4) \\
83.3(4) \\
80.9(3) \\
86.3(3) \\
91.7(3) \\
94.4(3) \\
94.8(4) \\
81(1)^{*} \\
75.5(5) \\
62.6(4) \\
58.9(8)^{*}\end{array}$ & $\begin{array}{l}- \\
- \\
- \\
- \\
- \\
- \\
- \\
13.5(6)^{*} \\
20.6(3) \\
34.1(3) \\
37.6(7)^{*}\end{array}$ & $\begin{array}{l}- \\
5.3(2) \\
14.0(2) \\
8.0(1) \\
2.6(2) \\
- \\
- \\
- \\
- \\
- \\
-\end{array}$ & $\begin{array}{l}1.9(1) \\
6.3(2) \\
- \\
- \\
- \\
- \\
- \\
- \\
- \\
- \\
-\end{array}$ & $\begin{array}{l}1.7(1) \\
- \\
- \\
- \\
- \\
- \\
- \\
- \\
- \\
- \\
-\end{array}$ & $\begin{array}{l}0.3(1) \\
0.8(1) \\
0.7(1) \\
0.2(1) \\
- \\
- \\
- \\
- \\
- \\
- \\
-\end{array}$ & $\begin{array}{l}4.3(1) \\
4.3(1) \\
4.4(1) \\
5.4(1) \\
5.7(1) \\
5.6(1) \\
5.2(1) \\
5.1(1)^{*} \\
3.9(1) \\
3.3(1) \\
3.5(1)^{*}\end{array}$ \\
\hline
\end{tabular}

* Rietveld refinement results from XRPD in transmission mode measured with capillaries. 
Table 2. Rietveld refinement results from XRPD patterns recorded in transmission mode on capillaries (lattice parameters a and $\mathrm{c}$, unit cell volume $\mathrm{V}$, atomic coordinates $\mathrm{x}, \mathrm{y}$ and $\mathrm{z}$, temperature factors $\mathrm{B}_{\text {iso }}$ and occupancies) for the two HAp phases from the 75Cu-1200 samples. Standard deviations are indicated in parentheses. $R_{p}=0.11$ and $\mathrm{R}_{\mathrm{wp}}=0.10$ represent conventional Rietveld agreement factors.

\begin{tabular}{l|l|l|l|l|l|l|l}
\hline HAp & Atom & Site & $x$ & $y$ & $z$ & $\begin{array}{l}\mathrm{B}_{\text {iso }} \\
\left(\AA^{2}\right)\end{array}$ & Occ.* \\
\hline
\end{tabular}

HAp1: Cu-poor HAp phase; $\mathrm{Ca}_{10} \mathrm{Cu}_{0.10(1)}\left(\mathrm{PO}_{4}\right)_{6}(\mathrm{OH})_{1.80(2)} \mathrm{O}_{0.20(2)}$

\begin{tabular}{l|l|l|l|l|l|l|l}
$P 63 / m$ & $\mathrm{Ca} 1$ & $4 f$ & $1 / 3$ & $2 / 3$ & $0.0023(4)$ & $0.5(1)$ & $1(-)$ \\
$a=9.42492(8) \AA$ & $\mathrm{Ca} 2$ & $6 h$ & $0.2468(3)$ & $0.9933(3)$ & $1 / 4$ & $=\mathrm{B}_{\mathrm{Ca} 1}$ & $1(-)$ \\
$c=6.88839(6) \AA$ & $\mathrm{P} 1$ & $6 h$ & $0.3992(3)$ & $0.3684(3)$ & $1 / 4$ & $0.3(1)$ & $1(-)$ \\
$\mathrm{V}=529.912(8) \AA^{3}$ & $\mathrm{O} 1$ & $6 h$ & $0.3264(7)$ & $0.4819(7)$ & $1 / 4$ & $0.5(1)$ & $1(-)$ \\
& $\mathrm{O} 2$ & $6 h$ & $0.5853(7)$ & $0.4658(7)$ & $1 / 4$ & $=\mathrm{B}_{\mathrm{O} 1}$ & $1(-)$ \\
& $\mathrm{O} 3$ & $12 i$ & $0.3406(4)$ & $0.2549(5)$ & $0.0705(5)$ & $=\mathrm{B}_{\mathrm{O} 1}$ & $1(-)$ \\
& $\mathrm{O} 4$ & $4 e$ & 0 & 0 & $0.203(2)$ & $=\mathrm{B}_{\mathrm{O} 1}$ & $1 / 2(-)$ \\
& $\mathrm{Cu} 1$ & $2 b$ & 0 & 0 & 0 & $=\mathrm{B}_{\mathrm{Ca} 1}$ & $0.048(6)$ \\
\hline
\end{tabular}

HAp2: Cu-rich HAp phase; $\mathrm{Ca}_{10} \mathrm{Cu}_{0.61(1)}\left(\mathrm{PO}_{4}\right)_{6}(\mathrm{OH})_{0.78(2)} \mathrm{O}_{1.22(2)}$

\begin{tabular}{l|l|l|l|l|l|l|l}
$P 6_{3} / m$ & $\mathrm{Ca} 1$ & $4 f$ & $1 / 3$ & $2 / 3$ & $0.0018(7)$ & $0.5(1)$ & $1(-)$ \\
$a=9.43954(9) \AA$ & $\mathrm{Ca} 2$ & $6 h$ & $0.2488(4)$ & $0.9933(4)$ & $1 / 4$ & $=\mathrm{B}_{\mathrm{Ca} 1}$ & $1(-)$ \\
$c=6.91356(7) \AA$ & $\mathrm{P} 1$ & $6 h$ & $0.3981(4)$ & $0.3677(4)$ & $1 / 4$ & $0.3(1)$ & $1(-)$ \\
$\mathrm{V}=533.500(9) \AA^{3}$ & $\mathrm{O} 1$ & $6 h$ & $0.330(1)$ & $0.486(1)$ & $1 / 4$ & $0.5(1)$ & $1(-)$ \\
& $\mathrm{O} 2$ & $6 h$ & $0.587(1)$ & $0.465(1)$ & $1 / 4$ & $=\mathrm{B}_{\mathrm{O} 1}$ & $1(-)$ \\
& $\mathrm{O} 3$ & $12 i$ & $0.3426(7)$ & $0.2591(7)$ & $0.0696(7)$ & $=\mathrm{B}_{\mathrm{O} 1}$ & $1(-)$ \\
& $\mathrm{O} 4$ & $4 e$ & 0 & 0 & $0.209(3)$ & $=\mathrm{B}_{\mathrm{O} 1}$ & $1 / 2(-)$ \\
& $\mathrm{Cu} 1$ & $2 b$ & 0 & 0 & 0 & $=\mathrm{B}_{\mathrm{Ca} 1}$ & $0.307(6)$ \\
\hline
\end{tabular}

* Occupancy parameters. 


\section{Supplementary Information}
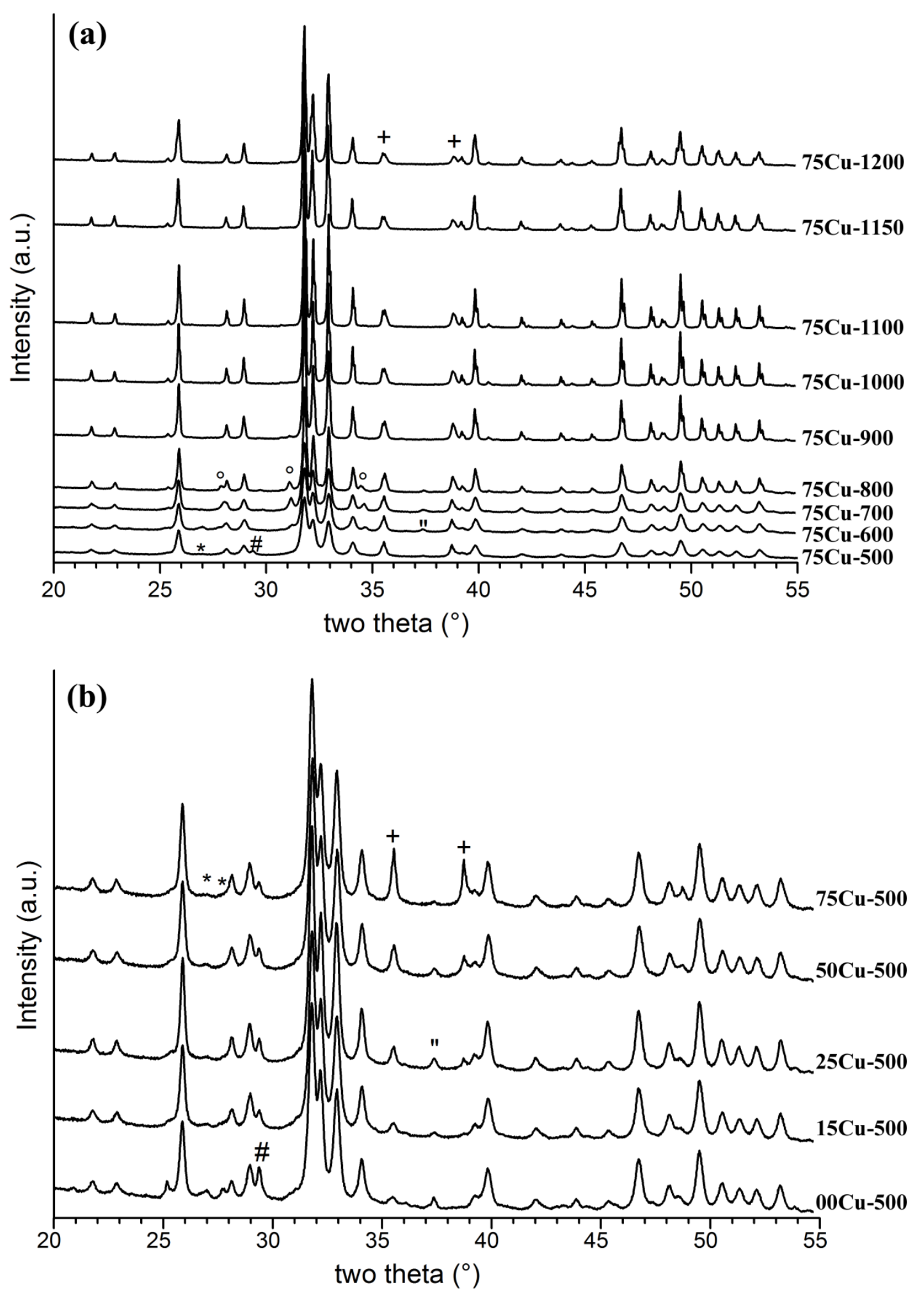

Figure SE1. Selected XRPD patterns ( $\lambda=1.5418 \AA$ ) showing (a) the $75 \mathrm{Cu}-T$ series and (b) the $x \mathrm{Cu}-500$ samples. Main phase is Hap for all patterns, minor phases are $\mathrm{CuO}(+), \beta$-TCP $\left(^{\circ}\right), \alpha-$ $\mathrm{CDP}(*), \mathrm{CaCO}_{3}(\#)$ and $\mathrm{CaO}(")$. 
Table SEI1. Structural parameters of the HAp phase obtained by Rietveld refinements.

\begin{tabular}{|c|c|c|c|c|c|}
\hline \multirow{2}{*}{ Samples } & \multicolumn{5}{|c|}{ HAp structural parameters } \\
\hline & $a(\AA)$ & $c(\AA)$ & $\mathrm{V}\left(\AA^{3}\right)$ & $\mathrm{Cu} \mathrm{Occ}{ }^{(* *)}$ & Refined composition \\
\hline $00 \mathrm{Cu}-500$ & $9.4196(1)$ & $6.88419(1)$ & $528.94(1)$ & - & $\mathrm{Ca}_{10}\left(\mathrm{PO}_{4}\right)_{6}(\mathrm{OH})_{2}$ \\
\hline $00 \mathrm{Cu}-600$ & $9.4197(1)$ & $6.88410(9)$ & $528.97(1)$ & - & $\mathrm{Ca}_{10}\left(\mathrm{PO}_{4}\right)_{6}(\mathrm{OH})_{2}$ \\
\hline $00 \mathrm{Cu}-700$ & $9.41874(9)$ & $6.88356(8)$ & $528.846(9)$ & - & $\mathrm{Ca}_{10}\left(\mathrm{PO}_{4}\right)_{6}(\mathrm{OH})_{2}$ \\
\hline $00 \mathrm{Cu}-800$ & $9.41954(5)$ & $6.88241(4)$ & $528.848(5)$ & - & $\mathrm{Ca}_{10}\left(\mathrm{PO}_{4}\right)_{6}(\mathrm{OH})_{2}$ \\
\hline $00 \mathrm{Cu}-900$ & $9.42007(3)$ & $6.88100(3)$ & $528.799(3)$ & - & $\mathrm{Ca}_{10}\left(\mathrm{PO}_{4}\right)_{6}(\mathrm{OH})_{2}$ \\
\hline $00 \mathrm{Cu}-1000$ & $9.42025(2)$ & $6.88127(2)$ & $528.840(2)$ & - & $\mathrm{Ca}_{10}\left(\mathrm{PO}_{4}\right)_{6}(\mathrm{OH})_{2}$ \\
\hline $00 \mathrm{Cu}-1100$ & $9.41972(3)$ & $6.88129(2)$ & $528.782(3)$ & - & $\mathrm{Ca}_{10}\left(\mathrm{PO}_{4}\right)_{6}(\mathrm{OH})_{2}$ \\
\hline $00 \mathrm{Cu}-1150$ & $9.41966(3)$ & $6.88177(3)$ & $528.812(3)$ & - & $\mathrm{Ca}_{10}\left(\mathrm{PO}_{4}\right)_{6}(\mathrm{OH})_{2}$ \\
\hline $00 \mathrm{Cu}-1200$ & $9.41942(3)$ & $6.88278(3)$ & $528.863(3)$ & - & $\mathrm{Ca}_{10}\left(\mathrm{PO}_{4}\right)_{6}(\mathrm{OH})_{2}$ \\
\hline $15 \mathrm{Cu}-500$ & $9,4156(5)$ & $6,8835(2)$ & $528,49(5)$ & $2.0(3)$ & $\mathrm{Ca}_{10} \mathrm{Cu}_{0.04(1)}\left(\mathrm{PO}_{4}\right)_{6}(\mathrm{OH})_{1.92(2)} \mathrm{O}_{0.08(2)}$ \\
\hline $15 \mathrm{Cu}-600$ & $9.4156(2)$ & $6.88559(9)$ & $528.65(1)$ & $1.5(3)$ & $\mathrm{Ca}_{10} \mathrm{Cu}_{0.03(1)}\left(\mathrm{PO}_{4}\right)_{6}(\mathrm{OH})_{1.94(2)} \mathrm{O}_{0.06(2)}$ \\
\hline $15 \mathrm{Cu}-700$ & $9,4170(1)$ & $6.8863(7)$ & $528,52(9)$ & $1.8(3)$ & $\mathrm{Ca}_{10} \mathrm{Cu}_{0.04(1)}\left(\mathrm{PO}_{4}\right)_{6}(\mathrm{OH})_{1.92(2)} \mathrm{O}_{0.08(2)}$ \\
\hline $15 \mathrm{Cu}-800$ & $9,41765(7)$ & $6,8824(4)$ & $528,79(5)$ & $1.6(3)$ & $\mathrm{Ca}_{10} \mathrm{Cu}_{0.003(1)}\left(\mathrm{PO}_{4}\right)_{6}(\mathrm{OH})_{1.94(2)} \mathrm{O}_{0.06(2)}$ \\
\hline $15 \mathrm{Cu}-900$ & $9,41951(4)$ & $6,8820(3)$ & $528,86(3)$ & $1.6(3)$ & $\mathrm{Ca}_{10} \mathrm{Cu}_{0.03(1)}\left(\mathrm{PO}_{4}\right)_{6}(\mathrm{OH})_{1.94(2)} \mathrm{O}_{0.06(2)}$ \\
\hline $15 \mathrm{Cu}-1000$ & $9,41886(3)$ & $6,88282(2)$ & $528,933(2)$ & $2.0(3)$ & $\mathrm{Ca}_{10} \mathrm{Cu}_{0.04(1)}\left(\mathrm{PO}_{4}\right)_{6}(\mathrm{OH})_{1.92(2)} \mathrm{O}_{0.08(2)}$ \\
\hline $15 \mathrm{Cu}-1100$ & $9,41749(3)$ & $6,88378(2)$ & $529,117(2)$ & $3.2(3)$ & $\mathrm{Ca}_{10} \mathrm{Cu}_{0.06(1)}\left(\mathrm{PO}_{4}\right)_{6}(\mathrm{OH})_{1.88(2)} \mathrm{O}_{0.12(2)}$ \\
\hline $15 \mathrm{Cu}-1150$ & $9.42192(2)$ & $6.88531(2)$ & $529.339(2)$ & $4.9(3)$ & $\mathrm{Ca}_{10} \mathrm{Cu}_{0.10(1)}\left(\mathrm{PO}_{4}\right)_{6}(\mathrm{OH})_{1.80(2)} \mathrm{O}_{0.20(2)}$ \\
\hline $15 \mathrm{Cu}-1200$ & $9.42291(2)$ & $6.88593(2)$ & $529.497(3)$ & $4.3(3)$ & $\mathrm{Ca}_{10} \mathrm{Cu}_{0.09(1)}\left(\mathrm{PO}_{4}\right)_{6}(\mathrm{OH})_{1.82(2)} \mathrm{O}_{0.18(2)}$ \\
\hline $25 \mathrm{Cu}-500$ & $9.41974(1)$ & $6.88150(1)$ & $528.80(1)$ & $1.5(3)$ & $\mathrm{Ca}_{10} \mathrm{Cu}_{0.03(1)}\left(\mathrm{PO}_{4}\right)_{6}(\mathrm{OH})_{1.94(2)} \mathrm{O}_{0.06(2)}$ \\
\hline $25 \mathrm{Cu}-600$ & $9.41584(1)$ & $6.88255(8)$ & $528.44(1)$ & $1.1(3)$ & $\mathrm{Ca}_{10} \mathrm{Cu}_{0.02(1)}\left(\mathrm{PO}_{4}\right)_{6}(\mathrm{OH})_{1.96(2)} \mathrm{O}_{0.04(2)}$ \\
\hline $25 \mathrm{Cu}-700$ & $9,41635(2)$ & $6.88243(7)$ & $528,492(8)$ & $1.5(3)$ & $\mathrm{Ca}_{10} \mathrm{Cu}_{0.03(1)}\left(\mathrm{PO}_{4}\right)_{6}(\mathrm{OH})_{1.94(2)} \mathrm{O}_{0.06(2)}$ \\
\hline $25 \mathrm{Cu}-800$ & $9,42051(4)$ & $6.88325(4)$ & $529.02(4)$ & $2.0(3)$ & $\mathrm{Ca}_{10} \mathrm{Cu}_{0.04(1)}\left(\mathrm{PO}_{4}\right)_{6}(\mathrm{OH})_{1.92(2)} \mathrm{O}_{0.08(2)}$ \\
\hline $25 \mathrm{Cu}-900$ & $9.41990(3)$ & $6.88176(2)$ & $528.84(3)$ & $1.8(3)$ & $\mathrm{Ca}_{10} \mathrm{Cu}_{0.04(1)}\left(\mathrm{PO}_{4}\right)_{6}(\mathrm{OH})_{1.92(2)} \mathrm{O}_{0.08(2)}$ \\
\hline $25 \mathrm{Cu}-1000$ & $9.42032(2)$ & $6.88217(2)$ & $528.92(3)$ & $1.9(3)$ & $\mathrm{Ca}_{10} \mathrm{Cu}_{0.04(1)}\left(\mathrm{PO}_{4}\right)_{6}(\mathrm{OH})_{1.92(2)} \mathrm{O}_{0.08(2)}$ \\
\hline $25 \mathrm{Cu}-1100$ & $9.42037(2)$ & $6.88304(2)$ & $528.99(3)$ & $4.8(3)$ & $\mathrm{Ca}_{10} \mathrm{Cu}_{0.10(1)}\left(\mathrm{PO}_{4}\right)_{6}(\mathrm{OH})_{1.80(2)} \mathrm{O}_{0.20(2)}$ \\
\hline $25 \mathrm{Cu}-1150$ & $9.42886(3)$ & $6.88700(2)$ & $528.58(3)$ & $6.4(3)$ & $\mathrm{Ca}_{10} \mathrm{Cu}_{0.13(1)}\left(\mathrm{PO}_{4}\right)_{6}(\mathrm{OH})_{1.73(2)} \mathrm{O}_{0.26(2)}$ \\
\hline $25 \mathrm{Cu}-1200$ & $9.42304(3)$ & $6.88703(3)$ & $529.596(3)$ & $6.2(3)$ & $\mathrm{Ca}_{10} \mathrm{Cu}_{0.12(1)}\left(\mathrm{PO}_{4}\right)_{6}(\mathrm{OH})_{1.76(2)} \mathrm{O}_{0.24(2)}$ \\
\hline $50 \mathrm{Cu}-500$ & $9,4139(2)$ & $6,88385(1)$ & $528,33(2)$ & $1.3(3)$ & $\mathrm{Ca}_{10} \mathrm{Cu}_{0.03(1)}\left(\mathrm{PO}_{4}\right)_{6}(\mathrm{OH})_{1.94(2)} \mathrm{O}_{0.06(2)}$ \\
\hline
\end{tabular}




\begin{tabular}{|c|c|c|c|c|c|}
\hline $50 \mathrm{Cu}-600$ & $9.41251(1)$ & $6.88434(1)$ & $528.21(1)$ & $1.2(3)$ & $\mathrm{Ca}_{10} \mathrm{Cu}_{0.02(1)}\left(\mathrm{PO}_{4}\right)_{6}(\mathrm{OH})_{1.96(2)} \mathrm{O}_{0.04(2)}$ \\
\hline $50 \mathrm{Cu}-700$ & $9,41509(9)$ & $6.88383(8)$ & $528,46(1)$ & $2.3(3)$ & $\mathrm{Ca}_{10} \mathrm{Cu}_{0.05(1)}\left(\mathrm{PO}_{4}\right)_{6}(\mathrm{OH})_{1.90(2)} \mathrm{O}_{0.10(2)}$ \\
\hline $50 \mathrm{Cu}-800$ & $9.41920(5)$ & $6.88293(4)$ & $528.85(5)$ & $2.3(3)$ & $\mathrm{Ca}_{10} \mathrm{Cu}_{0.05(1)}\left(\mathrm{PO}_{4}\right)_{6}(\mathrm{OH})_{1.90(2)} \mathrm{O}_{0.10(2)}$ \\
\hline $50 \mathrm{Cu}-900$ & $9.42006(3)$ & $6.88174(3)$ & $528.855(3)$ & $2.1(3)$ & $\mathrm{Ca}_{10} \mathrm{Cu}_{0.04(1)}\left(\mathrm{PO}_{4}\right)_{6}(\mathrm{OH})_{1.92(2)} \mathrm{O}_{0.08(2)}$ \\
\hline $50 \mathrm{Cu}-1000$ & $9.42061(3)$ & $6.88250(2)$ & $528.975(3)$ & $2.0(3)$ & $\mathrm{Ca}_{10} \mathrm{Cu}_{0.04(1)}\left(\mathrm{PO}_{4}\right)_{6}(\mathrm{OH})_{1.92(2)} \mathrm{O}_{0.08(2)}$ \\
\hline $50 \mathrm{Cu}-1100$ & $9.42062(3)$ & $6.88311(3)$ & $529.023(3)$ & $5.0(3)$ & $\mathrm{Ca}_{10} \mathrm{Cu}_{0.10(1)}\left(\mathrm{PO}_{4}\right)_{6}(\mathrm{OH})_{1.80(2)} \mathrm{O}_{0.20(2)}$ \\
\hline $50 \mathrm{Cu}-1150$ & $\begin{array}{l}9.42224(4) \\
9.42992(5)\end{array}$ & $\begin{array}{l}6.88620(3) \\
6.89622(4)\end{array}$ & $\begin{array}{l}529.442(5) \\
531.077(5)\end{array}$ & $\begin{array}{l}5.8(3) \\
13.7(6)\end{array}$ & $\begin{array}{l}\mathrm{Ca}_{10} \mathrm{Cu}_{0.12(1)}\left(\mathrm{PO}_{4}\right)_{6}(\mathrm{OH})_{1.76(2)} \mathrm{O}_{0.24(2)} \\
\mathrm{Ca}_{10} \mathrm{Cu}_{0.28(1)}\left(\mathrm{PO}_{4}\right)_{6}(\mathrm{OH})_{1.44(2)} \mathrm{O}_{0.56(2)}\end{array}$ \\
\hline $50 \mathrm{Cu}-1200$ & $\begin{array}{l}9.42175(4) \\
9.43046(5)\end{array}$ & $\begin{array}{l}6.88465(3) \\
6.89595(4)\end{array}$ & $\begin{array}{l}529.268(4) \\
531.117(5)\end{array}$ & $\begin{array}{l}4.7(3) \\
13.3(6)\end{array}$ & $\begin{array}{l}\mathrm{Ca}_{10} \mathrm{Cu}_{0.10(1)}\left(\mathrm{PO}_{4}\right)_{6}(\mathrm{OH})_{1.80(2)} \mathrm{O}_{0.20(2)} \\
\mathrm{Ca}_{10} \mathrm{Cu}_{0.27(1)}\left(\mathrm{PO}_{4}\right)_{6}(\mathrm{OH})_{1.46(2)} \mathrm{O}_{0.54(2)}\end{array}$ \\
\hline $75 \mathrm{Cu}-500$ & $9.41696(1)$ & $6.88298(1)$ & $528.60(1)$ & $1.1(3)$ & $\mathrm{Ca}_{10} \mathrm{Cu}_{0.02(1)}\left(\mathrm{PO}_{4}\right)_{6}(\mathrm{OH})_{1.96(2)} \mathrm{O}_{0.04(2)}$ \\
\hline $75 \mathrm{Cu}-600$ & $9.41390(1)$ & $6.88350(1)$ & $528.30(1)$ & $1.2(3)$ & $\mathrm{Ca}_{10} \mathrm{Cu}_{0.02(1)}\left(\mathrm{PO}_{4}\right)_{6}(\mathrm{OH})_{1.96(2)} \mathrm{O}_{0.04(2)}$ \\
\hline $75 \mathrm{Cu}-700$ & $9.4157(1)$ & $6.88321(8)$ & $528.48(1)$ & $2.1(3)$ & $\mathrm{Ca}_{10} \mathrm{Cu}_{0.04(1)}\left(\mathrm{PO}_{4}\right)_{6}(\mathrm{OH})_{1.92(2)} \mathrm{O}_{0.08(2)}$ \\
\hline $75 \mathrm{Cu}-800$ & $9.41878(5)$ & $6.88214(4)$ & $528.741(5)$ & $1.6(3)$ & $\mathrm{Ca}_{10} \mathrm{Cu}_{0.03(1)}\left(\mathrm{PO}_{4}\right)_{6}(\mathrm{OH})_{1.94(2)} \mathrm{O}_{0.06(2)}$ \\
\hline $75 \mathrm{Cu}-900$ & $9.41997(3)$ & $6.88171(3)$ & $528.842(3)$ & $2.1(3)$ & $\mathrm{Ca}_{10} \mathrm{Cu}_{0.04(1)}\left(\mathrm{PO}_{4}\right)_{6}(\mathrm{OH})_{1.92(2)} \mathrm{O}_{0.08(2)}$ \\
\hline $75 \mathrm{Cu}-1000$ & $9.42008(3)$ & $6.88201(2)$ & $528.878(3)$ & $2.2(3)$ & $\mathrm{Ca}_{10} \mathrm{Cu}_{0.04(1)}\left(\mathrm{PO}_{4}\right)_{6}(\mathrm{OH})_{1.92(2)} \mathrm{O}_{0.08(2)}$ \\
\hline $75 \mathrm{Cu}-1100^{*}$ & $\begin{array}{l}9.42269(3) \\
9.4326(3)\end{array}$ & $\begin{array}{l}6.88514(3) \\
6.9059(2)\end{array}$ & $\begin{array}{l}529.411(3) \\
532.13(3)\end{array}$ & $\begin{array}{l}3.1(3) \\
21.8(6)\end{array}$ & $\begin{array}{l}\mathrm{Ca}_{10} \mathrm{Cu}_{0.06(1)}\left(\mathrm{PO}_{4}\right)_{6}(\mathrm{OH})_{1.88(2)} \mathrm{O}_{0.12(2)} \\
\mathrm{Ca}_{10} \mathrm{Cu}_{0.44(1)}\left(\mathrm{PO}_{4}\right)_{6}(\mathrm{OH})_{1.12(2)} \mathrm{O}_{0.88(2)}\end{array}$ \\
\hline $75 \mathrm{Cu}-1150$ & $\begin{array}{l}9.42261(5) \\
9.43379(8)\end{array}$ & $\begin{array}{l}6.88714(4) \\
6.90985(8)\end{array}$ & $\begin{array}{l}529.555(5) \\
532.564(9)\end{array}$ & $\begin{array}{l}6.7(3) \\
27(1)\end{array}$ & $\begin{array}{l}\mathrm{Ca}_{10} \mathrm{Cu}_{0.13(1)}\left(\mathrm{PO}_{4}\right)_{6}(\mathrm{OH})_{1.74(2)} \mathrm{O}_{0.26(2)} \\
\mathrm{Ca}_{10} \mathrm{Cu}_{0.54(1)}\left(\mathrm{PO}_{4}\right)_{6}(\mathrm{OH})_{0.92(2)} \mathrm{O}_{1.08(2)}\end{array}$ \\
\hline $75 \mathrm{Cu}-1200^{*}$ & $\begin{array}{l}9.42492(8) \\
9.43954(9)\end{array}$ & $\begin{array}{l}6.88839(6) \\
6.91356(7)\end{array}$ & $\begin{array}{l}529.912(8) \\
533.500(9)\end{array}$ & $\begin{array}{l}4.8(3) \\
30.4(6)\end{array}$ & $\begin{array}{l}\mathrm{Ca}_{10} \mathrm{Cu}_{0.10(1)}\left(\mathrm{PO}_{4}\right)_{6}(\mathrm{OH})_{1.80(2)} \mathrm{O}_{0.20(2)} \\
\mathrm{Ca}_{10} \mathrm{Cu}_{0.61(1)}\left(\mathrm{PO}_{4}\right)_{6}(\mathrm{OH})_{0.78(2)} \mathrm{O}_{1.22(2)}\end{array}$ \\
\hline
\end{tabular}

* Rietveld refinement results from XRPD in transmission mode measured with capillaries.

$* * \mathrm{Cu}$ occupancy $(\%)$ in the interstitial $2 b$ Wyckoff site. 
Table SEI2. Structural parameters of the $\beta$-TCP phase obtained by Rietveld refinements.

\begin{tabular}{|l|l|l|l|l|l|l|}
\hline Samples & \multicolumn{7}{|c|}{$\beta$-TCP structural parameters } \\
& $a(\AA)$ & $c(\AA)$ & $\begin{array}{l}\mathrm{Cu} \text { Occ } \\
\text { in Ca4 }\end{array}$ & $\begin{array}{l}\mathrm{Cu} \text { Occ in } \\
\mathrm{Ca} 5(*)\end{array}$ & Refined composition \\
\hline $00 \mathrm{Cu}-800$ & $10.4260(2)$ & $37.3689(8)$ & $3517.85(9)$ & - & - & $\mathrm{Ca}_{3}\left(\mathrm{PO}_{4}\right)_{2}$ \\
\hline $15 \mathrm{Cu}-700$ & $10.3925(2)$ & $37.3302(8)$ & $3491.68(2)$ & $25(4)$ & $39(3)$ & $\mathrm{Ca}_{2.82(3)} \mathrm{Cu}_{0.18(3)}\left(\mathrm{PO}_{4}\right)_{2}$ \\
\hline $25 \mathrm{Cu}-700$ & $10.38324(2)$ & $37.30476(8)$ & $3483.06(9)$ & $21(6)$ & $36(6)$ & $\mathrm{Ca}_{2.84(3)} \mathrm{Cu}_{0.16(3)}\left(\mathrm{PO}_{4}\right)_{2}$ \\
\hline $50 \mathrm{Cu}-700$ & $10.37699(2)$ & $37.30045(9)$ & $3478.46(2)$ & $4(2)$ & $48(6)$ & $\mathrm{Ca}_{2.85(3)} \mathrm{Cu}_{0.15(3)}\left(\mathrm{PO}_{4}\right)_{2}$ \\
\hline $75 \mathrm{Cu}-700$ & $10.3642(3)$ & $37.2859(3)$ & $3468.53(8)$ & $42(8)$ & $48(6)$ & $\mathrm{Ca}_{2.74(3)} \mathrm{Cu}_{0.26(3)}\left(\mathrm{PO}_{4}\right)_{2}$ \\
\hline
\end{tabular}

* Cu occupancy in the $\mathrm{Ca} 4$ and $\mathrm{Ca} 5$ crystallographic site of the $\beta$-TCP structure. 


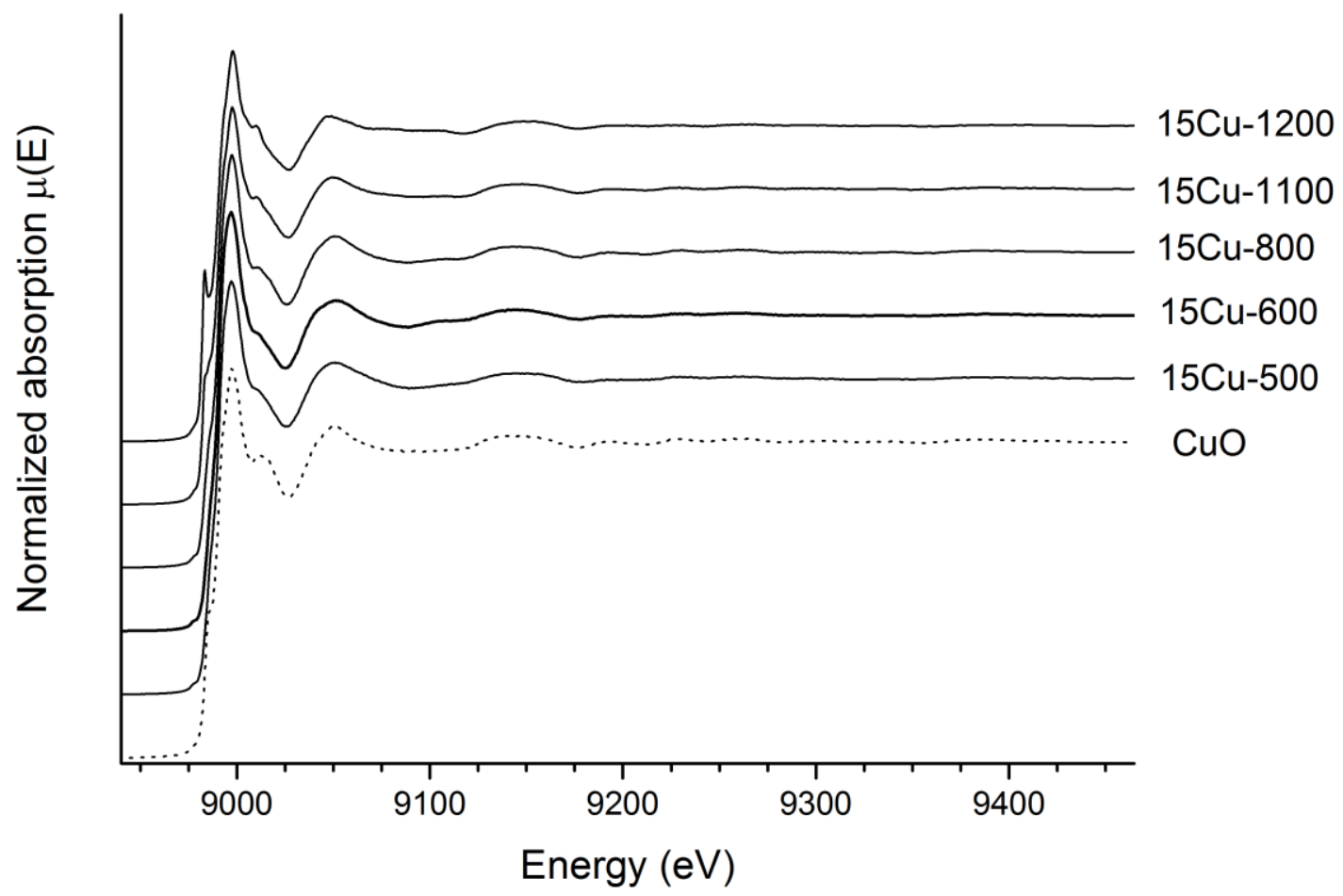

Figure SEI2. Normalized EXAFS spectra at the $\mathrm{Cu}$ K edge $\left(\mathrm{E}_{0}=8982 \mathrm{eV}\right)$ for the $15 \mathrm{Cu}-T$ series samples (solid lines) and the reference $\mathrm{CuO}$ compound (dashed lines). 


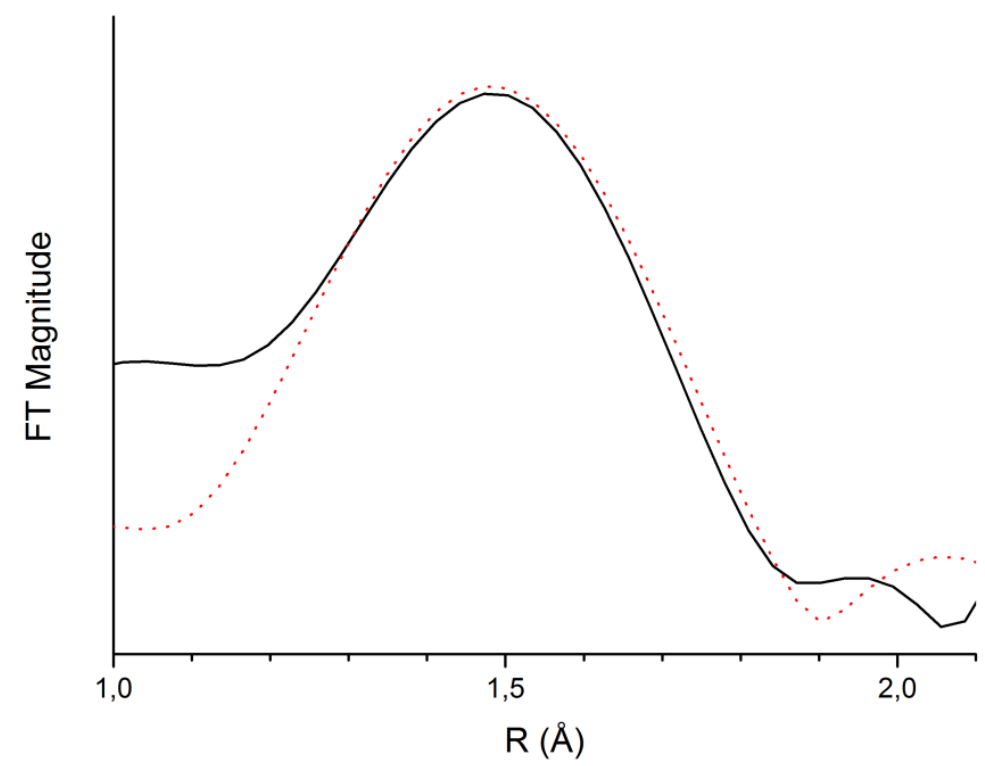

Figure SEI3. The $k^{3}$-weighted amplitude of the Fourier transform uncorrected for phase shift (black line) and best fit in $R$-space (dotted red line) for the first $\mathrm{Cu}$-shell in $15 \mathrm{Cu}-1200$ (independent points: 5, variables: 2 , and $R$-factor: 0.0734 ). 


\section{Comment SEI1. XPS assignment signals.}

Samples from the $75 \mathrm{Cu}-\mathrm{T}$ series were analyzed by XPS spectroscopy in order to confirm the presence of $\mathrm{Cu}^{+}$cations for heat treatments above $1100^{\circ} \mathrm{C}$. Note that the $\mathrm{Cu} 2 \mathrm{p}_{3 / 2}$ signal is stable during XPS analysis, which indicates that no reduction of copper oxides takes place under the $\mathrm{X}$-ray beam. In the case of copper-based compounds, reference compounds like metallic $\mathrm{Cu}$, $\mathrm{Cu}_{2} \mathrm{O}$ and $\mathrm{CuO}$ have to be analyzed first in order to definitively characterize formal oxidation states $\mathrm{Cu}^{0}, \mathrm{Cu}^{+}$and $\mathrm{Cu}^{2+}[59]$. For metallic copper and $\mathrm{Cu}_{2} \mathrm{O}$ standard samples, $\mathrm{Cu} 2 \mathrm{p}_{3 / 2}$ analysis reveals the presence of a peak located respectively at $932.6 \mathrm{eV}$ and $932.7 \mathrm{eV}$, confirming that these two compounds cannot be precisely identified by their $\mathrm{Cu} 2 \mathrm{p}$ core peak position. A slight difference in the $\mathrm{Cu} 2 \mathrm{p}$ signature can be observed, since very weak satellite peaks are detected for the $\mathrm{Cu}_{2} \mathrm{O}$ sample at higher binding energies, between 942.0 and $948.0 \mathrm{eV}$, associated with minor contributions from $\mathrm{Cu} \mathrm{d}^{9}$ initial state configurations [60], while no satellite structure is observed for metallic copper.

For the $\mathrm{CuO}$ sample, the main $2 \mathrm{p}_{3 / 2}$ peak presents a component located at $933.6 \mathrm{eV}$, attributed to $\mathrm{Cu}^{2+}$ atoms characteristic of the $\mathrm{CuO}$ phase. The other XPS peaks located at higher binding energies can be attributed to satellite peaks $(940-945 \mathrm{eV})$. According to the literature $[61,62]$, the detection of two well-separated lines (main line at $933.6 \mathrm{eV}$ and satellite line in the range of 940-945 eV) can be interpreted by the occurrence of two different final states for $\mathrm{CuO}$ : the $3 \mathrm{~d}^{10} \mathrm{~L}^{-1}$ configuration (ligand-to-metal charge transfer during the photoemission process) and the $3 \mathrm{~d}^{9} \mathrm{~L}$ configuration (the same as the initial state). The main asymmetric line has no splitting, and is therefore ascribed to a $3 \mathrm{~d}^{10} \mathrm{~L}^{-1}$ valence-band configuration since the $3 \mathrm{~d}$ shell of the ionized copper atom is completely filled. The satellite line is quite structured and at least three components can be observed $(940.8,942.3$ and $943.9 \mathrm{eV})$; it is assigned to the $3 \mathrm{~d}^{9} \mathrm{~L}$ configuration. For this last assignment, the $3 \mathrm{~d}$ shell of the ionized copper is partially filled and the open $2 p$ and $3 d$ shells will give rise to multiplet-split final, ionic, states. Finally, the $\mathrm{Cu} 2 \mathrm{p}_{3 / 2}$ 
signature of $\mathrm{CuO}$ is very different with respect to that of $\mathrm{Cu}_{2} \mathrm{O}$ and $\mathrm{Cu}$, as the satellite peaks at ca. $6 \mathrm{eV}$ above the principal line are characteristic of $\mathrm{Cu}^{2+}$ in an oxygen environment. Note that Auger electrons are also created under X-ray radiation, and their corresponding peaks also contain theoretical information about the chemical environment of the element. The metallic copper Auger spectrum presents a well-resolved fine structure [60], this structure being not present for the copper oxide Auger spectra. 


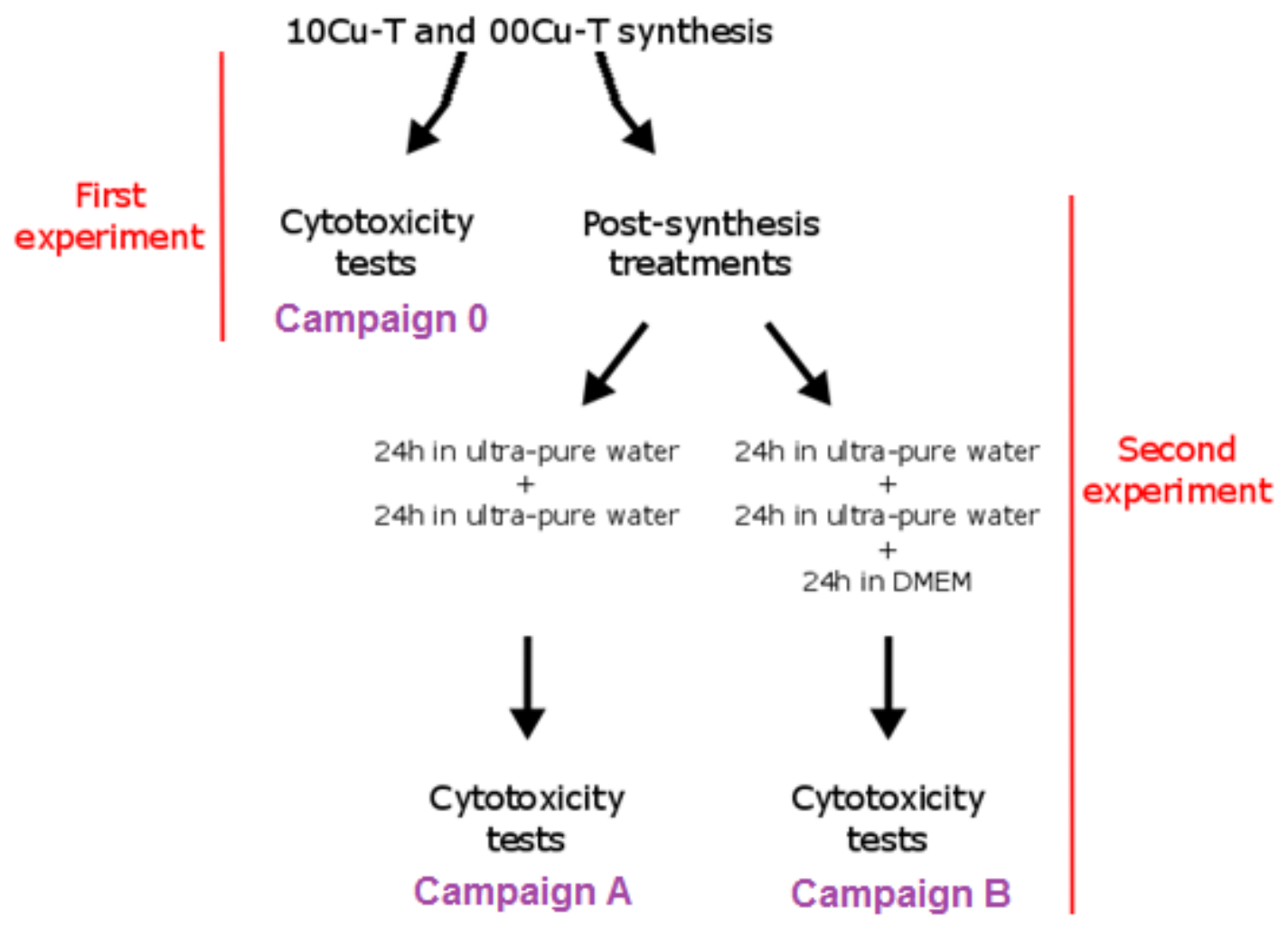

Figure SEI4. Scheme summarizing samples preparation for cytotoxicity evaluation. 